
PRIVATE LERARY
P. U. OAARA

$\because \cdots$ 



\section{FUNGOID DISEASES}

OF

FARM AND GARDEN CROPS 



\section{FUNGOID DISEASES}

$\mathrm{OF}$

\section{FARM AND GARDEN CROPS}

BY

THOMAS MILBURN, Ph.D., N.D.A., N.D.D.

SECRETARY OF AGRICULTURE, LANCASHIRE COUNTY COCNCIL, AND LECTURER IX AGRICLITLRE, LANCASHIRE COUNTY COUNCIL AGRICULTURAL SCHOOL, HARRIS INSTITLTE, PRESTON ; LATE LECTURER ON PLANT DISEASES AT THE: MIDLAND AGRICULTURAL COLLEGE, KINGSTON, DERBY

IVITH A PREFATORY NOTE BY

E. A. BESSEY, M.A., Pн.D.

PROFESSOR OI BOTANY, MICHIGAN AGRICULTURAL COLLEGE, EAST IAASING; LATE PATHOI.UGIST IN CHARGE OF UNITED STATES DEPARTMENT OF AGRICULTURE'S SUBTROPICAL,

LABORATORY FOR PLANT DISEASES AT MIAMI, FLORIDA; FORMERIY PATHOLOGIST IN THE BUREAU OF PLANT INDUSTRY, UNITED STATES DEPARTNENT OF AGRICULTURE, WASHINGTON

WITH DIAGRAMS

L ONGMANS, GREEN A N C C.

39 PATERNOSTER ROW, LONDON FOURTH AVENUE \& 30r"I STREET, NEW YORK BOMBAY, CALCUTTA, AND MADRAS 
S8733

. 1748 


\section{PREFATORY NOTE.}

By E. A. BESSEY, M.A., Pн.D.

THat crops are subject to diseases of various kinds, has been known for thousands of years. In the Bible we find reference to mildews and blasted crops, while among the Roman writers a number of different diseases were recognized. As early as the middle of the eighteenth century, considerable study had been made of some of the fungi which caused plant diseases, but even as late as the third and fourth decade of the nineteenth century, there were some scientific agriculturists who insisted that the spots and discolorations caused by fungi, or the spore masses of these fungi, were but parts of the plant itself, while even to the present day, some persons regard such: epidemics as punishment or warnings sent by the: Almighty to a sinful people. The brilliant researches, however, of the great British and German mycologists of the middle of the nineteenth 
century for ever dispelled these views among enlightened scientists and gave the first impetus toward the study of plant diseases from a rational standpoint. We now know that aside from the injuries caused by insects or other animals, nearly every cultivated plant is subject to attack by few or many parasitic fungi or bacteria. In addition to these diseases and to those caused by unfavourable climatic or soil conditions, there are also some diseases, well marked in their character and so far as we can determine, absolutely nonparasitic in origin, the cause of which appears to be spontaneous to the plant. Such diseases offer a fine field for investigation by the thoroughly trained student.

As the causes of plant diseases became known, attempts were made to develop rational methods of combating them. Thus the mycologists were succeeded by the plant pathologists who attempted to determine not only the cause of each disease, but the conditions favourable and unfavourable to its development. In the case of diseases caused by parasitic organisms, it became necessary to follow out in detail every step of the life history of these organisms in their relation to their hosts, 
so that their methods of entry and their vulnerable periods could become known. The development of fungicides, especially Bordeaux mixture, was a natural result of the realization that fungi are the causes of most plant diseases. The newest researches now attempt to correlate what is known of the life history of the parasite and of its manner of entering the host with the facts learned as to the relation of the weather to infection, and to plan the application of fungicides accordingly. Another line of research is the development of the resistant types of crops, but this is for the plant breeder, primarily.

In the present book, the author attempts to present, in a form capable of being understood both by students and by agriculturists, a brief discussion of each of the more important diseases of the common field and garden crops. Of necessity such a book cannot be complete as to all diseases known on all crops. Indeed, such a work would be undesirable and so bulky as to be almost useless. The author has approached the subject with a practical understanding of what is wanted in such a book by the agriculturist who frequently lacks the technical knowledge to 
understand some of the more pretentious technical works on the subject. On the other hand, he has not sacrificed scientific accuracy in his attempt to make the book one that can be understood. It is, then, a book to become acquainted with which will well repay the student who wishes to learn something of the commoner diseases of these crops.

The writer of this preface has had the pleasure of reading the whole manuscript and of making suggestions and comments, many of which have commended themselves to the author and have been adopted by him. If these suggestions and additions may serve to make this book more valuable, the writer of this preface feels that he has been amply rewarded.

\section{E. A. BESSEY.}

\section{Mímigan Agricultural College, \\ East Lansing, Michigan, U.S.A.}




\section{AUTHOR'S PREFACE.}

This introduction to the study of Plant Diseases has been compiled primarily for the use of Farmers, Gardeners, and Agricultural Students, but it is hoped that it may have a wider field of influence, and that those engaged in teaching and County lecturing may find in its pages material of interest and of value.

I have aimed at simplicity in definition and have not attempted too much detail of a purely scientific nature. I am aware of its incompleteness, but its size precludes the inclusion of the more minor diseases and of fuller details in the case of those diseases treated. I hope, however, that any deficiency in detail will be compensated for by the points of special merit, and that it may be found worthy of a place on every agriculturist's bookshelf.

Many of the drawings are original, and where otherwise are duly acknowledged. 
I desire to acknowledge my indebtedness to my good friend E. A. Bessey, M.A., Ph.D., Professor of Botany, Michigan Agricultural College, for kindly writing the Prefatory note and the subject matter on pages 29, 30, 33-3\$, 79 and 83 ; for reading the whole of the proofs and for many other valuable suggestions and additions.

To any others who have assisted me either directly or indirectly I tender my best thanks.

\title{
THOMAS MILBURN.
}

\author{
County Offices, \\ Preston, July, I 9 I 5.
}




\section{CONTENTS.}

PAGES

Prefatory Note

v-viii

Author's Preface ix-x

CHAPTER I.

GENERAL INFORMATION

CHAPTER II.

Fungoid Diseases of Cereals . . . . 39-62

CHAPTER III.

Fungold Diseases of Legunnots Plants (Peas, BEANS, ETC.) . . . . . . . 63-74

CHAI'TER IV.

Fungoid Diseases of POTATOES

CHAPTER V.

Fungold Disfases of Crucifents (Turnips, Cabbage, ITC.)

- $94-102$

CHAPTER V'I.

FUNGOH, DISEASE OF MANGELS AND BEET . . IO3.108

APPENDIX.

Fungoll DISEASE OF FarM AxIMALS

. $109-113$ INDEX . 



\section{FUNGOID DISEASES OF FARM AND GARDEN CROPS.}

\section{CHAPTER I.}

GENERAL INFORMATION.

THE diseases described in the subsequent pages of this book are caused by fungi (low forms of vegetable life) which rob the larger plants of part of their nourishment. The term fungi, however, is somewhat vague, hence it will be well at the outset to state definitely in what light the word will be used. In its wider sense it embraces not only the true fungi, but also the bacteria, while in the narrower light it includes the true fungi only-bacteria coming in a separate class. Practically all the diseases described herein are caused by the true fungi, and hence the term is used throughout in its narrower sense. ${ }^{1}$ Everyday examples of true fungi are to be found in the various moulds on fruit, jam, cheese, and in the mushrooms, toadstools, mildews, etc.

A classification of fungi is given on p. 34, where

${ }^{1}$ A few diseases not caused by true fungi will be described, but these will be noted in the text. 
it will be seen that they form a number of classes which have probably arisen by the degeneration (it may be said through the loss of chlorophyll) of forms in various groups of green, or at least chlorophyll-containing, low water-plants called alge. Owing to their being devoid of chlorophyll, they are entirely dependent for their food on matter already built up, either by higher plants, or by animals. Those deriving their nourishment from living organic matter are called parasites, others deriving it from dead matter are called saprophytes (see p. I 2).

Before passing on to the actual plant diseases, a few botanical terms must be described and a little general information given in order to make the context of the book more easily understood.

Hypha.-Most fungi have their vegetative part (the body of the fungus, or that part which takes up food) in the form of very fine delicate threads called hyphre (Fig. I), which are mostly invisible, singly, to the naked eye. They are in reality, fine transparent tubes containing a semi-fluid substance called protoplasm, which is the vital part. It circulates slowly inside these tubes, and in it are embedded numerous nuclei, fat globules, etc. Growth of the hyphæ takes place at the tip.

Mycelium.-Usually the hypha do not remain long as single threads, but branch and re-branch, becoming thereby interlaced and forming what is 
termed the mycelium (Fig. I). This mycelium then is nothing more than a network of hyphre which, when a fungus has grown some time, is visible to the naked eye, as seen in the grey covering called mildew on turnips and other plants, and in the white or green mould on bread and cheese.

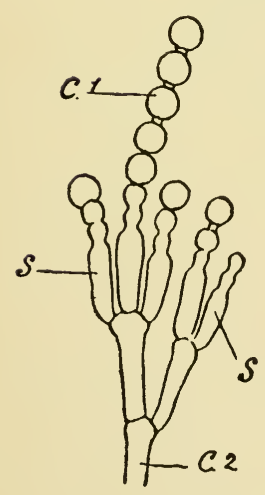

A

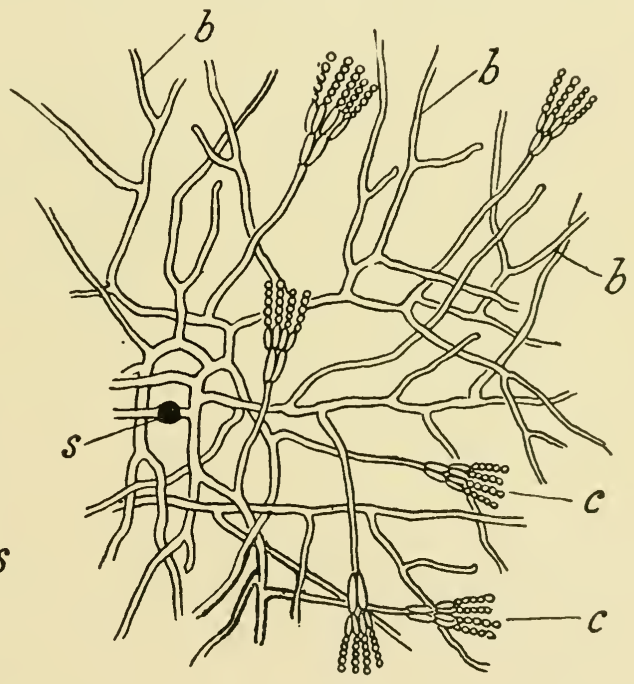

B

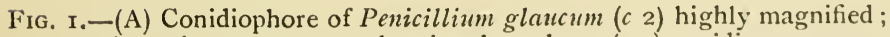
(s. s.) sterigmata or spore-bearing branches; (c r) conidia or spores; (B) portion of mycelium of Penicillium which has developed from the spore $(s) ; b . b . b$. branches or hyphæ; notice the brush-like groups of conidia. (After Brefeld.)

The words hyphæ and mycelium often form a stumbling-block to students, and consequently the following illustration is given with a view to making them clearer. If we take a single thread drawn from 
a piece of cotton-wool to represent a hypha, then several such threads represent the hyphæ; and a little of the wool spread out thinly corresponds to the mycelium.

Sporangiophore and Conidiophore.-After "feeding" for a time, certain aerial hyphæ grow out from the mycelium, on which spores are subsequently

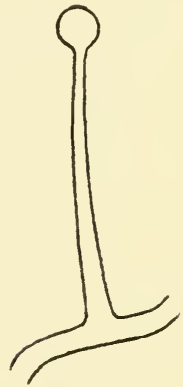

A

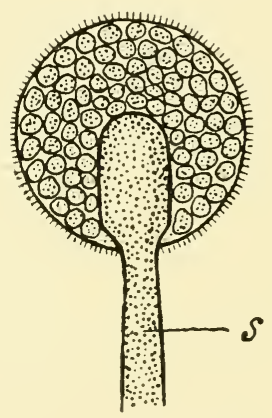

B

FIG. 2.-Mucor mucedo-(A) Showing the formation of a sporangium ;

(B) the sporangium full grown containing the oval spores. The stalk $(s)$ is called a sporangiophore. (Highly magnified.)

formed. If the spores are enclosed in a sac (e.g. Mucor mucedo, Fig. 2) these aerial hyphæ are called sporangiophores, if they are borne externally on branches the aerial hyphæ are called conidiophores.

Sclerotia.-Under certain conditions-usually when food or moisture is lacking-the hyphæ, at certain points of the mycelium, branch and interlace to such an extent that firm felted masses called sclerotia result. These sclerotia are hard and 
usually dark coloured ; and the hypha forming them are rich in food substances. They constitute a resting stage, in that they can withstand cold, drought, etc. ; and after a longer or shorter period of rest, are capable of starting growth (see p. 55 , under ergot). When sections of sclerotia are examined under the microscope they resemble, to some extent, the tissue of the higher plants.

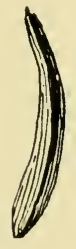

A

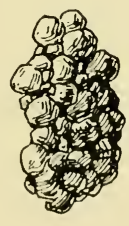

B

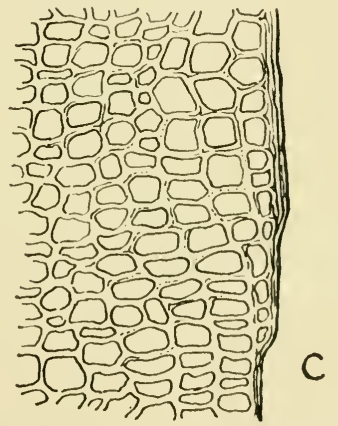

FIG. 3.-(A) Sclerotium of Claviceps purpurea (Eirgot) ; (B) Sclerotium of Sclerotinia trifoliornm; (C) Is a section through a sclerotium showing cell-like appearance, somewhat diagrammatic and highly magnified.

Haustoria (Suckers).-Parasitic fungi which live on the surface of the host plant (e.g. Erysiphe'), and many of those living in the intercellular spaces (e.g. Puccinia graminis), are provided with special organs, for the absorption of food, called haustoria, or suckers.

These haustoria are modified portions of the hyphæ, and are of no fixed form (Fig. 4). In the Erysiphacee they consist of foot-like expansions 
firmly attached to the leaf surface, which send a very fine thread into the inside of the cells of the host. This fine thread forms a sack-like swelling inside, which gives a larger surface for the absorption of food. There is, however, greater variety of form in the haustoria of those fungi which live inside the plant (endophytic). Saprophytic fungi, and those parasitic fungi which live inside the cells of the

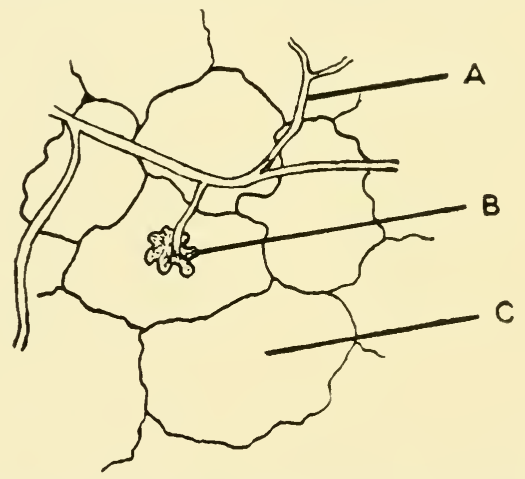

FIG. 4.-Showing the formation of a haustorium or sucker; (B) in a species of Erysiphe; (A) the hyphæ; (C) the surface cells of the leaf. (Somewhat diagrammatic.)

host, are not so dependent on these special organs for the absorption of food, as in their case it can be taken in over the entire surface of the hypha.

Spores.-These are extremely minute portions of protoplasm which become separated from the parent fungus for the purpose of reproducing its kind, serving the same function for the fungus that seeds do for the higher plants. They are usually -though not always - surrounded by a protective 
covering-the wall of the spore. There are a variety of types, but for convenience we may class them under two heads :-

(a) Those which are formed as a result of some sexual union, e.g. oospores, zygospores, etc.

(b) Those formed asexually, i.e. not-so far as is known-by any sexual act, e.g. conidia, endospores, chlamydospores.

Under each of these heads the shape of the spores is very varied. They may be :-

Round as in Penicillium glaucum,

Oval as in Mucor mucedo,

Angular as in Oidium lactis,

Crescent shaped as in Fusarium solani,

Needle shaped as in Claviceps purpurea (ascospores),

Kidney shaped as in many Basidiomycetes; indeed, diversity in shape may be noticed in spores growing side by side on the same branch. Irrespective of the shape, most fungus spores are easily carried in the atmosphere from place to place; where they may either be capable of immediate germination, or they may remain dormant for a considerable time prior to growth. In either case a new centre of infection is set up by each individual spore thus carried.

Germination of Spores. - The germination of spores, and the growth of a fungus generally, are best studied by making what are called drop cul- 
tures, and observing the changes from time to time under the microscope. They may be made as follows :-

Upon a piece of ordinary glass $3 \frac{1}{2}$ in. $\times$ I in. (Fig. 5, A) place a small piece of cardboard $^{1}$ (B)

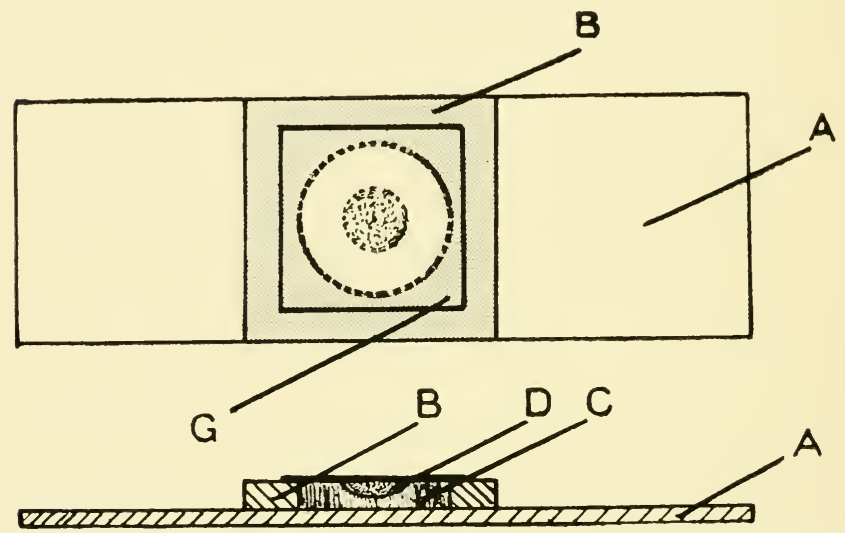

FIG. 5.-Sketch showing how drop cultures are made, on which the germination of spores and growth of fungi may be observed direct under the microscope. Also shown in section. Description in text.

about one inch square, having a hole $(\mathrm{C})$ in the centre. Take a very thin piece of glass one inch in diameter (cover glass) clean and sterile, and place upon it, by means of a glass rod, a drop of sterile water or other substance. ${ }^{2}$

Place the smallest possible number of spores on

${ }^{1}$ Boil the cardboard for one minute prior to using, and keep all glass and instruments used as sterile as possible.

${ }^{2}$ Various substances are used, e.g. prune juice, dung extract, sugar solutions, beer wort, etc.; some spores germinating best in one, some in another. All substances used must be germ free. 
the drop by means of a very fine platinum needle, then invert and place over the cardboard (B). The drop of nutriment which has been inoculated with the desired spores now hangs from the cover glass in the chamber $(\mathrm{C})$ formed by the slide below, the hole in the cardboard, and the cover glass above. Without disturbing this in any way the growth of the spores may be studied by frequent examination under the microscope. ${ }^{1}$

The change which spores undergo when placed upon such a drop depends upon the composition of the liquid forming the drop, and in part to the surrounding conditions. The spores of many parasitic fungi refuse to germinate in almost any solution; others will germinate in one solution but not in another, e.g. spores of Tilletia (bunt) germinate freely in water but refuse to grow when placed in drops of food solutions. Then again some spores give different changes in different liquids, e.g. spores of Ustilago (smut) germinate in water and very dilute food solutions; but in solutions containing abundant nutriment they multiply by a process called budding.

The typical germination of a spore consists in the protrusion of a portion of the wall which gradually develops into a delicate tube (Fig. 6, B); this

${ }^{1}$ It is advisable to keep at a medium temperature, and place inside moist chambers, as this keeps the drop of nutriment from drying up. 
branches and re-branches, ultimately forming the mycelium which is capable of unlimited growth under favourable conditions. Many spores are capable of germination after passing through the body of an animal; the wall of the spores having resisted the effect of the digestive juices. This is a point of great importance, and one that should never be lost sight of in combating the attack of any particular fungoid disease.

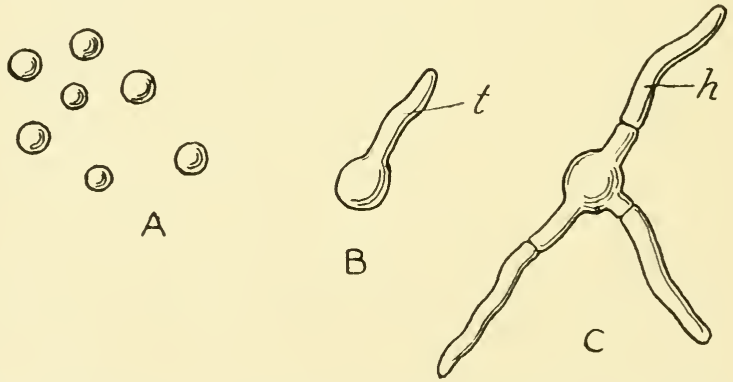

Fig. 6.-Showing germination of the spores of Penicillium glaucum: (A) the spores before germination; (B), (C) successive stages in germination; $(t)$ the germ tube. In (C) cross walls have been formed in the hypha $(h)$. (Highly magnified.)

Reproduction.-We have just seen that quite a variety of spores are formed, by the different fungi, for the purpose of reproduction, some forming one kind, some another; but what is even more interesting is the fact that the same fungus may form more than one kind. Many examples might be given, but perhaps one of the most striking amongst parasitic fungi is Puccinia graminis (rust), which 
forms on wheat uredospores and teleutospores; while the same fungus when growing on the barbery (Berberis vulgaris) produces aecidiospores and picnospores.

On making a study of saprophytic fungi, it is found that the particular form of spore produced depends upon the conditions of food, temperature, air supply, moisture, etc. ; provided these remain constant, so does the form of the spore; but change any or all of the factors, and a change in the spore formation usually results. Moving the mycelium of some fungi from a rich nutritive medium into a poorer one, or into distilled water, will immediately result in a change of fructification. In a similar manner lack of water, or lack of food, will cause change. It will be seen then that diversity in the type of reproduction serves a most useful purpose to the fungus in case of emergencies; in that although the conditions may be unfavourable to growth, and the mycelium may die in consequence, the spores remain to perpetuate the species, when and if more favourable conditions are afforded. In combating any disease this should be carefully borne in mind.

Just as gooseberry bushes may be increased in number by putting detached portions under favourable conditions for growth, so also can small portions of mycelium serve to increase the amount of fungus growth. This method of increase, however, 
sinks into insignificance under the profuse production of spores.

Parasites ${ }^{1}$ and Saprophytes.-According to the source of food, we divided fungi into parasites and saprophytes (see page 2). This division, however, is somewhat arbitrary, for many parasitic fungi are capable of living wholly or partly as saprophytes. In like manner, some saprophytes are able to exist as parasites. A better division is as follows :-

I. Totally Parasitic.-Fungi whose whole life is spent on living matter, and which, so far as our present methods of cultivation allow, will not grow on dead organic substances, e.g. the Uredinales (rusts) and the different species of Erysiphacere (mildews).

2. Semi-parasitic.-Fungi which are capable of growth for all, or part, of their life cycle as sapro. phytes, but which are typically found parasitic for part, or all, of this cycle. The smuts are capable of growth indefinitely as saprophytes, but do not produce the typical smut spores unless they grow as parasites; on the other hand all stages of the potato fungus (Phytophthora) can be grown saprophytically, although in nature it is commonly found only as a parasite.

${ }^{1}$ A parasite may be looked upon as a robber of the plant, and stands in much the same relation to the host as a lazy fellow does to his victim, from whom he obtains food and money. 
3. Totally Saprophytic.-Fungi which are unable to exist as parasites, and which in consequence do not cause disease to either plants or animals. They merely play the part of scavengers, hastening the decay of refuse matter.

4. Hemi-saprophytic. - Fungi which live chiefly as saprophytes, but which are able to exist either partly or totally as parasites, e.g. various species of Mucor and Penicillium; or even more so the different species of Polyporus-seen as sponge-like masses on trees-which, as parasites, are able to kill living cells, but are also capable of living totally saprophytic.

Each of these four heads might be sub-divided, but for this work it will suffice to divide the purely parasitic fungi into :-

(a) Epiphytic - parasites which live on the surface of the host, e.g. species of Erysiphacere (mildews).

(b) Endophytic-parasites which live inside the plants; either in the intercellular spaces (the space between the cells) or inside the cells, e.g. Phytophthora infestans inside the cells of the diseased potato.

Effect of Parasite on the Plant.-The changes brought about by parasitic fungi are exceedingly varied; the plant may succumb to the attack of the fungus in a few days, e.g. as seen in the "damping off" of cress, or the host and parasite may live together for a long time without disastrous results, 
as seen in the brain-like swellings on such trees as the elm. In some cases the invaded tissues are killed, in others only certain tissues or only certain areas, while often the fungus simply robs the affected tissues of certain food stuffs so that death does not occur; indeed the tissue may be stimulated to abnormally active growth.

The injury due to the presence of the fungus itself may be very slight but its consequences farreaching. The destruction of leaf tissues by many fungi leads to starvation of the whole plant owing to the destruction of the food manufacturing organs (leaf tissues); so also a fungus may simply destroy the root hairs (the fine feeding roots), the death of the plant resulting from the destruction of these water-absorbing organs. The rust of wheat (Puccinia graminis) is chiefly injurious in that it splits the stems and so permits them to dry out. In many cases the fungus secretes poisons which pass to various parts of the plant causing various reactions.

Some of the results of parasitic attack are mentioned below :-

I. Sudden collapse of the host as abovementioned.

2. Plant and parasite may live together for years, with comparatively slight alteration of tissue, e.g. species of Exoascus on trees.

3. Abnormal fruit, e.g. Exoascus prumi, causing the disease known as "pocket plums". 
4. Abnormal flowering - where the attacked part flowers at a different time from the rest of the plant, e.g. "witches' broom" on the cherry tree.

5. Suppression of part of the reproductive organs, e.g. Ustilago (smut) on Lychnis dioica (campion).

6. Premature development of buds, e.g. a diseased potato usually develops the buds earlier than the healthy ones, and the same phenomenon is seen in the "witches' broom" on the elder.

7. Contortions of the most varied nature, e.g. Cystopus candidus on Capsella bursa pastoris (shepherd's purse).

8. Discoloration of the parts affected-most fungi.

9. Formation of different colours, e.g. Rhizoctonia, violet on roots, and Fusarium (species), rose-pink on potatoes.

IO. Cell wall and cell contents changed by means of ferments, e.g. wall and starch grains in a diseased potato.

Others might be given, but these will suffice to convey to the mind of the reader the great changes which are brought about.

Influence of Host on Parasite. - While parasites are able to bring about such contortions, etc., in plants, these in turn are not without their effect on the attacking party. Certain fungi are only capable of existing on plants of a particular genus; others again on a single species, while some can only 
make " healthy" growth on certain varieties of the same species. The different varieties of wheat, barley, potatoes, etc., show marked differences in the power of warding off the attacks of their respective diseases; e.g. while one variety of potato ${ }^{1}$ forms a suitable feeding ground for Phytophthora, and falls a prey to disease in consequence; another is unfavourable to its development and as a result suffers less from the attack. This diversity is due in a great measure to the difference in the relative amounts of the various chemical substances within the plant. Influence of plant on parasite is again shown where a change of the host results in the formation of a different kind of spore, as is well instanced in Puccinia graminis which forms on wheat uredo- and teleuto-spores, while on the barbery (Berberis) aecidiospores are produced; again Cystopus candidus (producing white rust in crucifers) on shepherd's purse forms only conidia, while on some other plants belonging to the same order another kind of spore is formed, viz. oospore.

The above examples show that the host exerts a very considerable influence on the parasite.

Signs of Disease. - The various changes enumerated under "Effect of Parasite on Plant" (p. I3) indicate the presence of some attack. These

${ }^{1}$ Grown under identical conditions, some varieties may have over two tons of diseased tubers to the acre, e.g. "Up-to-Date," and others not as many cwts., e.g. "King Edward VII". 
abnormal conditions may be classed under three heads, viz. :-

I. Discoloration,

2. Abnormal outgrowths,

3. Death,

the two latter of which may, or may not, be preceded by the former. Change in colour, however, may be said to be one of the most frequent results of disease attack; such change may be reduction of the natural colour generally, or, what is of more frequent occurrence, the local formation of new colour.

We see then how important it is that the farmer should train his eye-already quick at observing most things-to detect any change in colour in part, or the whole, of his crop; for if disease be present, it may still be possible, by applying stimulating manures to the soil, or fungicides to the leaf, to mitigate the extent of the attack; growth of the plants being assisted by the former, and healthy plants protected by the latter.

Diagnosis of Disease. - Abnormalities of any kind having been noticed in a few or many plants, it is essential that some idea should be formed as to the cause, if preventive measures are to be adopted to limit the extent of the attack, and here comes the farmer's difficulty. A small pocket magnifying glass will often reveal much that is obscure to the naked eye-no student of agri- 
culture or farmer should be without one-but for a more critical examination a microscope is necessary.

Spread of Disease. - The spread of disease may be brought about in a variety of ways, the chief of which are enumerated below :

I. Movement of disease spores in the atmosphere by wind.

2. Spores or diseased parts of plant carried by animals, man, implements, etc.

3. Transportation of infected soil by animals, implements, etc.

4. Growth of fungus from centre of infection.

The spores which constitute the chief form of reproduction in parasitic fungi are exceedingly minute, and when detached from the fungus threads most of them are easily carried by the wind from place to place, thus spreading the disease. This is well instanced in the spores of the fungus causing potato disease (Phytophthora) which are carried from field to field; and accounts for the rapidity of its increase, and extent of its devastation, under favourable conditions (see later). These same spores, and those of other fungi not carried by wind, may become attached to the feet or bodies of insects, birds, rabbits, man, implements, etc., and thus disseminate the disease. Diseased plants when carted from the root shed and thrown on previously uninfected areas cause direct contamination, as also does the manure from cattle which have eaten diseased 
plants or seeds, for many spores are not attacked by the digestive juices of the stomach and are thus capable of germination under favourable conditions. Birds carry diseased fruits from place to place. Soil from an infected area may be carried by implements, etc., to different parts of the same, or other fields, e.g. spread of "finger-and-toe" disease. Diseases spread in this manner, i.e. carried by animals, etc., although by no means easy to check, can be more successfully prevented than those whose spores are carried by the wind.

How Fungi Gain Admission to the Plant.-It is not definitely known how many parasitic fungi gain entrance to the healthy plant, but it may be in one of three ways :--

I. Digestion of the cell wall.

2. Through the breathing pores.

3. At some wound.

The delicate germ tube which protrudes on germination is in some cases capable of gaining an entrance to the plant by digesting the wall with the ferments which it secretes. The germ tube of Phytophthora, although usually entering at a breathing pore, is also capable of digesting the cell wall, while hyphe of Sclerotinia sclerotionm are capable of piercing the cell walls of a variety of plants. The number of fungi entering in this way is, however, probably over-estimated, for some minute wound can often be detected. 
The second mode of entrance is found in those fungi whose spores are disseminated by the wind, e.g. the germ tube from the zoospore of Phytophthora, if near a stoma, enters it, being attracted by certain food substances - " chemotropism".

The third method of entrance, i.e. through some wound, is the most widespread, indeed it is highly probable that many fungi which are said to enter in other ways gain admission in this manner. Many parasitic fungi may be placed on the surface of a healthy plant, where the epidermis is intact, without gaining an entrance; but should the least abrasion be made, inoculation is almost certain. This is well illustrated in the pruning of large trees; if no dressing is applied to the cut surface Polypoms or some other fungus usually finds an easy entrance and ultimately causes decay of the parts.

The root hairs of the plant are delicate organs, and hence it seems fair to conclude that some fungi enter plants through them. When other channels of infection prove uncertain a fungus is said, either rightly or wrongly, to pass in via these hairs, but as before mentioned, some of the cases attributed to such entrances are more or less obscure, e.g. Plasmodiophora brassica.

Natural Conditions Favouring the Spread of Fungoid Diseases. I. Weather Conditions. - A moist atmosphere combined with warmth provides the optimum conditions for fungoid development, 
disease spores being unable to germinate without these. Unfortunately the farmer has no direct control over the weather, but indirectly he can keep the plants drier by giving them more space. The effect of moisture is well seen in the case of a field of potatoes; the four rows next to the hedge, almost without exception, suffer more from the Phytophthora disease than any other part of the field. This is so marked that in certain districts the farmers hold firmly to the opinion that the disease comes from the trees which constitute the hedge.

On the other hand lack of moisture may favour some diseases, e.g. certain forms of leaf curl in potatoes. Again, the moisture content of the soil during the early stages in the growth of swedes may profoundly influence the extent of finger-and-toe disease in the subsequent crop, as is shown in the undermentioned case which the author investigated:

Half of a large field sown Sth June, poor crop, $S$ I per cent diseased.

Half of same field sown i 5 th June, good crop, I I per cent diseased.

The cultivation, manuring, and previous cropping of the two halves, were the same, but the weather about the time of the first sowing was dry while immediately after the second sowing there were heavy rainfalls on three successive days.

2. Crowded Cropping:-Most plants are more susceptible to disease when grown closely together : 
this is due to their not drying so quickly after rain as when more space is given.

3. Continued Cropping:-Where plants are grown continuously on the same land, a suitable host is always at hand for the disease-producing fungi, and spread of disease is favoured thereby.

4. Diversity in Host.-Even when crops are not grown continuously, if weeds be allowed to flourish in the interval, some of these may act as host until the same crop is repeated; for it is known that some fungi are capable of existing on many, or all, of the plants of a certain order; a good example being found in Plasmodiophora brassica, which is capable of living, during the interval between the turnip crops in the rotation, on cruciferous weeds, should such be present. This fact is favourable to the continuance and spread of disease.

5. Badly Nourished Crops.-Crops which are ill-nourished usually succumb more readily to disease than those in a robust condition; swedes grown where phosphate is deficient suffer more from the attacks of Plasmodiophora than those having an adequate supply of this substance. Potatoes appear to be more susceptible to the attack of certain forms of leaf curl when low in vitality.

6. Adaptability to Varied Conditions.-The fact that many plant parasites are able to adapt themselves to the most varied conditions favours attacks. When privations of any kind set in then resting 
spores are formed, which are capable of withstanding variations of temperature, and subsequently germinating under favourable conditions. In other cases sclerotia (see p. 4) are found.

7. Transportation of Spores - Wounds.-Spores are distributed either by wind or otherwise, and on germination set up new centres of infection. Entrance to the plant is made easier by the presence of wounds, as seen on page 20, and like the other above-mentioned facts, favours non-extermination.

Natural Conditions Unfavourable to Spread of Disease.-From a cursory glance it would appear as though everything was in favour of the growth of parasitic fungi ; fortunately such is not the case. Dry cold weather retards their growth, the cutinized (hardened) epidermis of the plant makes entrance more difficult, and by far the largest bulk of disease spores find themselves deposited in places unfavourable to their development. Furthermore, the extent to which some varieties of a particular species of plants are able to resist disease attack, affords evidence that parasitic fungi meet with natural factors which limit very considerably the extent of their ravages.

Amount of Damage Done by Fungi.-The loss which any particular farmer suffers from a fungoid attack is in itself serious, but it is only when we take statistics for the whole country that we fully realize the amount of damage done. Take potatoes 
as an example, the loss in a "disease year" is appalling.

According to the returns of the Board of Agriculture for the year I9I 2, the area under potatoes in the United Kingdom was I, 2 I 9, 583 acres, with an average crop of about 6 tons to the acre. This gives a total of $7,317,498$ tons, which at $£_{2}$ per ton are worth $\mathcal{E}_{\mathrm{i} 4}, 634,996$; but assuming that disease is rampant, and that one-fourth of the crop is diseased, if we take the value of the diseased tubers at ros. per ton, the total value of the whole would be EI I, 890,934 instead of $\mathcal{E}_{\mathrm{I}} 4,634,996$, which means

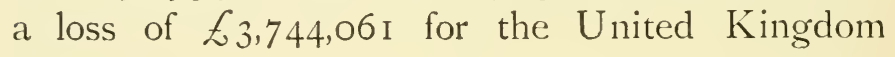
alone.

The losses from grain rust for Prussia alone have been estimated at millions for a single year, while the loss in Australia due to rust in wheat is put at $2 \frac{1}{2}$ million pounds for one year.

The above figures are only approximate, still they give us some idea of the extent of the damage, and impress upon us the importance of adopting preventive and remedial measures whenever possible.

Fungicides. - Cultural and other preventive measures based upon the afore-mentioned favourable and unfavourable conditions will be given later in the text, but it will be well to enumerate here a few of the common fungicides, and the methods of preparation. 
I. Bordeaux mixture.

2. Soda-Bordeaux.

3. Soda-lime Bordeaux.

4. Copper sulphate solution.

5. Hot water.

6. Potassium sulphide.

7. Formaldehyde.

8. Corrosive sublimate.

9. Lime-sulphur.

IO. Flowers of sulphur.

I. Bordeaux Mixture.-This mixture was first prepared by Millardet in 1885 , and has since been subjected to numerous modifications. Even at the present day different strengths are recommended by various authorities. It is, and is likely to remain, the most important fungicide, being popular on account of :

I. Its effectiveness as a fungicide.

2. Its cheapness.

3. Its safety from a hygienic standpoint.

4. Its safety to the plant. ${ }^{1}$

5. Its beneficial effects other than checking disease. ${ }^{1}$

The active principle in the mixture is the copper. which in very dilute solutions is poisonous to fungi -some succumb to solutions containing one part of

${ }^{1}$ Recent results obtained in Lancashire (L.C.C. Farmers' Bulletin, No. 27) and elsewhere tend to modify our ideas regarding these points ; however, further research is necessary. 
copper per ten million. The exact composition is unknown, for it varies according to the manner of preparation, the degree of purity of the lime, and the copper used. When freshly prepared it consists essentially of a saturated watery solution of calcium sulphate and calcium hydroxide, containing in suspension calcium sulphate and copper hydroxide and a varying amount of calcium hydroxide and calcium carbonate. When exposed to the air the calcium hydroxide takes up carbon dioxide, forming calcium carbonate which is washed away by subsequent rains. Whether the copper hydroxide undergoes any change is doubtful, no change is probable until the whole of the calcium hydroxide has been neutralized, when it may become changed to carbonate. ${ }^{1}$

Preparation.-Strict attention should be paid to the instructions given below, for on the proper mixing, and purity of the chemicals used, depends the value of the resulting solution as a fungicide. No exact formula can be given, as it is always necessary to test the solution before applying, but the following will be found about the correct proportions :- ${ }^{2}$

${ }^{1}$ See "U.S. Dep. of Agr., Division of Vegetable Physiology and Pathology Bull.," No. 9, I896, and for more recent work, Pickering, "Jour. of Agr. Sc.," vol. iii. part 2, p. 17 1, and vol. iv. part 3, p. 273 ; Gimmingham and Barker, "Jour. of Agr. Sc.," vol. iv. part I, pp. 69 and 76 ; vol. 6, part 2, p. 220.

${ }^{2}$ The amount of copper sulphate is sometimes reduced to equal the amount of lime. 
I 2 lbs. copper sulphate.

ro lbs. lime (freshly burnt).

roo gallons water.

Three wooden vessels are necessary for the proper mixing; two small and one double their size-paraffin barrels answer well for small quantities. Powder the copper sulphate, put in a piece of sacking, and dissolve in half the water in one of the small vessels. Slake the lime in the other small vessel with the remaining water. When the lime wash is cooled, pour the contents of the two vessels, after stirring, both at the same time into the large receptacle. The resulting solution should be tested in one of the following ways: for if too much lime be present it is useless as a fungicide, if too little, it is dangerous to the crop.

(a) Ferrocyanide Test.-Add one drop of a solution of potassium ferrocyanide to the mixture; if the colour of the drop changes to a dark, reddish brown, more lime is necessary, if no change in colour, the mixture is safe to apply.

(b) Hold a clean knife blade, or other bright surface of steel, in the mixture for one minute, if on removal it is clean, the solution is safe to use ; if copper is deposited on the surface of the blade, more lime must be added.

(c) Litmus Paper.-After the liquid has settled 
a little dip a piece of blue litmus paper into it; if the paper remains blue the mixture is safe to use, if not add more lime and repeat the test.

After straining and repeated stirring, apply in the form of a fine spray in the quantities stated under the respective diseases-usually from 40 to 8o gallons per acre. For small areas a knapsack sprayer answers very well, but for larger areas a horse sprayer should be used.

2 and 3. Soda-Bordeaux and Soda-Lime Bordeaux. - The above are modifications of the original Bordeaux Mixture; their preparation is somewhat critical, and since they possess no effectual advantage over the original solution, details as to mixing will not be given.

4. Copper Sulphate Solution.-Very dilute solutions of copper sulphate are sometimes used instead of the Bordeaux Mixture, but since they are more liable to injure the host plant, and do not stick to the surface so well, they are not to be recommended for general adoption. Dilute solutions are, however, of great value for the treatment of seed grain for smut and bunt. A common recipe for this purpose is the following : I lb. copper sulphate and I gallon of water for each sack of wheat; the grain being spread on the floor and the mixture applied by means of a watering can, while the grain is being turned. The above mixture is a ro per cent 
solution, and is far too strong, the germination of the grain being sometimes impaired to a serious extent.

A better method of prevention is to resort to the hot water treatment, or to use more dilute solutions of copper sulphate. Kühn recommends the following: soak the seed in $\frac{1}{2}$ per cent solution of copper sulphate $^{1}$ for I 2 to 16 hours, remove and dry 24 hours prior to drilling and 4 hours prior to sowing broadcast. It is an advantage if the grain subsequent to the removal from the copper sulphate solution be put for 3 to 4 minutes in thin milk of lime.

5. (A) Jensen's Hot Water Treatment.-This has been successfully adopted in place of the copper sulphate solutions for the prevention of certain smuts and bunt.

Three vessels are necessary :-

(1) containing water at $212^{\circ} \mathrm{F}$.

(2) containing water at $\mathrm{I} 20^{\circ} \mathrm{F}$.

(3) containing water at $133^{\circ} \mathrm{F}$.

The grain should be put into wire baskets for treatment, or open, coarse sacks, which will do equally well, First immerse for I minute in No. (2) in order to warm it a little prior to putting into No. (3) ; now draw out and immerse in No. (3) for Io minutes, agitating the mass the whole time. After the lapse of Io minutes lift out, dip into cold water to cool it, and spread on a floor to dry.

${ }^{1}$ The grain may be put in open canvas bags for immersion. 
Water from No. ( 1 ) is used to keep up the bulk and temperature of Nos. (2) and (3). If properly carried out the warm water not only kills the spores of bunt or smut, but also favours subsequent germination of the grain.

Necessary Precautions.-

(a) Maintain the temperature of the water in No. (3) vessel.

(b) Never have it above I $30^{\circ} \mathrm{F}$. for barley, the embryo of which is easily injured by higher temperatures.

(c) Never allow it to rise above $135^{\circ} \mathrm{F}$. for other grain.

(d) Have the volume of water at least eight times as large as that of the sack containing the grain.

(e) Do not fill the sack, but allow free movement of the grain.

(f) Keep the grain in No. (3) exactly Io minutes.

$(g)$ Do not leave in a thick layer after treatment, but spread out to dry.

With a badly infested sample of wheat the bunted grains should be removed by throwing the whole in water-they float on the surface and may be skimmed off.

(B) Jensen's Modified Hot Water Treatment for Loose Smut of Barley and Wheat.-Soak the grain in cold water $\left(60^{\circ}\right.$ to $70^{\circ} \mathrm{F}$.) for 4 or 5 hours; remove, dip for a moment into a vessel of water at $\mathrm{I}_{2} \mathrm{O}^{\circ} \mathrm{F}$, then for barley immerse for 
I 3 minutes in water at $126^{\circ} \mathrm{F}$. and for wheat IO minutes at $\mathrm{I} 29^{\circ} \mathrm{F}$, remove to cold water and dry rapidly. If the grain is to be sown immediately, dry only enough to permit of sowing, otherwise dry completely. An accurate (tested) thermometer should be used. Decrease the time by about 4 or 5 minutes for each degree in temperature above those stated, but in no case exceed $129^{\circ} \mathrm{F}$. for barley and $\mathrm{I}_{3} \mathrm{I}^{\circ} \mathrm{F}$. for wheat. Increase the time by the same amount for each degree below the temperature recommended, but do not let the temperature fall below I $2 \mathrm{I}^{\circ} \mathrm{F}$. The grain should be put in wire baskets and constantly agitated so that the grains may all be heated. The temperature should be watched closely and kept up to the desired degree by additions of hot water.

6. Solution of Potassium Sulphide (Liver of Sulphur).-This solution loses strength on standing and is best prepared as required for use in the following proportions :-

Potassium sulphide

$2 \mathrm{Oz}$.

Water.

4 gallons

Mix in a wooden vessel and apply by means of a syringe or sprayer on a calm day, to gooseberry and rose trees which are suffering from mildew.

7. Corrosive Sublimate Solution.-This solution may be used as a preventive for scab, but it is now in many cases supplanted by the more convenient, 
and equally effective, formaldehyde solution. It should be prepared in the following proportions :

Corrosive sublimate . . I $\mathrm{Oz}$.

Water. . . . 7 gallons

For scab and other superficial diseases of the potato, soak the tubers in this solution for $I \frac{1}{2}$ hours at least 4 weeks prior to planting. This solution must be used for Rhizoctonia disease of potatoes as formaldehyde solution is ineffective. Corrosive sublimate is a deadly poison, and hence care must be exercised in handling it.

S. Formaldehyde Solutions.-As a preventive of scab in potatoes, bunt and some smuts in grain, solutions of formaldehyde have proved most effectual. They should be prepared in the proportions stated below .

(a) For Potato Scab.

Formaldehyde. I pint (40 per cent solution) Water . . . . 30 gallons

Place the potatoes in a coarse sack, immerse in the liquid for about two hours, and then spread out to dry. If very dirty the seed potatoes should be washed prior to treatment.

(b) For Smut of Oats and covered Smut of Barley. Formaldehyde . I pint (40 per cent solution)

Water

30-40 gallons

Thoroughly sprinkle the grain with the solution, using a watering can for the purpose while the grain is being turned over on the floor, leave it in a 
heap covered with canvas for several hours before spreading out to dry. Another method is to put the grain in a half-filled sack and dip it into the solution, agitating to ensure contact of the solution with the whole of the grains, then drain and spread out to dry.

(c) For Bunt.-Pour part of the grain to be treated into the formaldehyde solution ( I pint of commercial formalin to 40-45 gallons of water), and stir so that the bunted grains may all rise to the top and be skimmed off and destroyed. Drain off the solution into another vessel, then remove the treated grain and spread out to dry. Replace the solution, add more grain, and proceed as before.

9. Lime-Sulphur Solution.-This compound is obtainable commercially in a concentrated form, or may be made by the user. It is an excellent contact insecticide, especially for scale insects on fruit trees, but has also great fungicidal value and can be used on some plants which cannot endure copper fungicides (e.g. peach and Jananese plums). It should not be used on potatoes nor on grapes. If combined with poison for biting insects, the best results are obtained by using arsenate of lead, 2-3 lb. of the dry powdered form, or twice as much of the paste form, to 100 gallons of the solution. As a winter spray lime-sulphur may be used much more concentrated than after the foliage appears. It should be tested with a Baumé Hydrometer. It 
is used largely for fruit trees, and fuller details regarding its preparation will be found in books dealing with diseases of fruit trees.

Io. Flowers of Sulphur.-This is sometimes dusted on the leaves to check mildew attack on small areas.

NoTE.-For further information on spray mixtures and spraying machinery, see "New York Exp. Station Bulletin," No. 243; Pickering, Gimmingham, and Barker, l.c. p. 26 ; also "Standard Fungicides," by G. F. Strawson (Simpkin, Marshall \& Co.).

Classification of Fungi.-The Vegetable Kingdom (following Engler) is divided into twelve divisions, the twelfth of which consists of seedbearing plants, and the tenth the true fungi. Perhaps a more natural arrangement is that of Professor Charles E. Bessey, who divides the Vegetable Kingdom into fourteen Phyla. Of these fourteen Phyla the last five represent different groups of seed-bearing plants. Fungi are found in two distinct Phyla, viz. : Siphonophycea, which consists of two classes of green algre and one class (Phycomycetea) of fungi, and Carpomycetere (the Higher Fungi) containing three classes: Ascomycetere (or Ascosporece), Basidiomycetece (or Basidiosporea), and Teliosporece.

The Phycomycetea have no direct relationship with the Higher Fungi, but rather with the green algx belonging to the other classes of the Phylum -Siphonophycece; while the Higher Fungi have 
their closest relationship with the red seaweeds forming the sixth Phylum-Rhodophycea.

Besides these four classes of fungi there occur in some other classes of normally green alge a few representatives that have assumed the fungus habit, e.g. the Synchytriacee in Class Protococcoidece in the Phylum Chlorophycea.

The four chief classes of fungi, however, are distinguished as follows:-

Class Phycomycetea (Lcwer Fungi). Vegetative hyphae without cross walls (except in old age, after injury, or to set-off the reproductive organs). There are four orders :

(a) Saprolegniales with five or more families.

(b) Peronosporales with two families.

(c) Mucorales with four or more families.

(d) Entomophthorales with one or two families.

Class Ascomycetere (Sac Fungi). Vegetative hypha septate. Perfect stage of reproduction characterized by the formation of ascopores (usually eight in number) in ovoid or cylindrical sacs called asci. There are fifteen or more orders, and over one hundred families; many of them are important parasites, and some form the organisms known as lichens.

Class Basidiomyceted. Vegetative hyphat septate. Perfect stage of reproduction with (usually four) basidiospores formed on short or long stalks (sterigmata) from ovoid or club-shaped basidia. There 
are nine or more orders and twenty to twenty-five families. The common mushroom, puff-ball, and bracket or ear fungi belong to this group.

Class Teliosporece. Vegetative hyphe septate. Parasitic for the whole, or most of the life cycle. Perfect stage of reproduction by the production of teliospores (teleutospores or sometimes chlamydospores) which bear on germination a short promycelium on which are borne sporidia. This class is often merged with the preceding as a sub-class in which the pro-mycelium and sporidia are called basidium and basidiospore respectively.

Two orders - Ustilaginales the smuts (with two families, Ustilaginacea - the smuts, and Tilletiacere -the bunts), and Uredinales the rusts with three families.

Besides these there is recognized an artificial group, the Fungi Imperfecti, consisting of fungi of which only the vegetative or conidial stage is known, the perfect stage probably belonging most frequently to the Ascomycetere but in some cases to the Basidiomycetere. There are three or four orders and about ten families.

The accompanying table represents a schematic arrangement of the Vegetable Kingdom, illustrating by the relative areas of the classes the relative number of species in each, while the solid lines represent their probable relationships within the various phyla and the broken lines the probable 


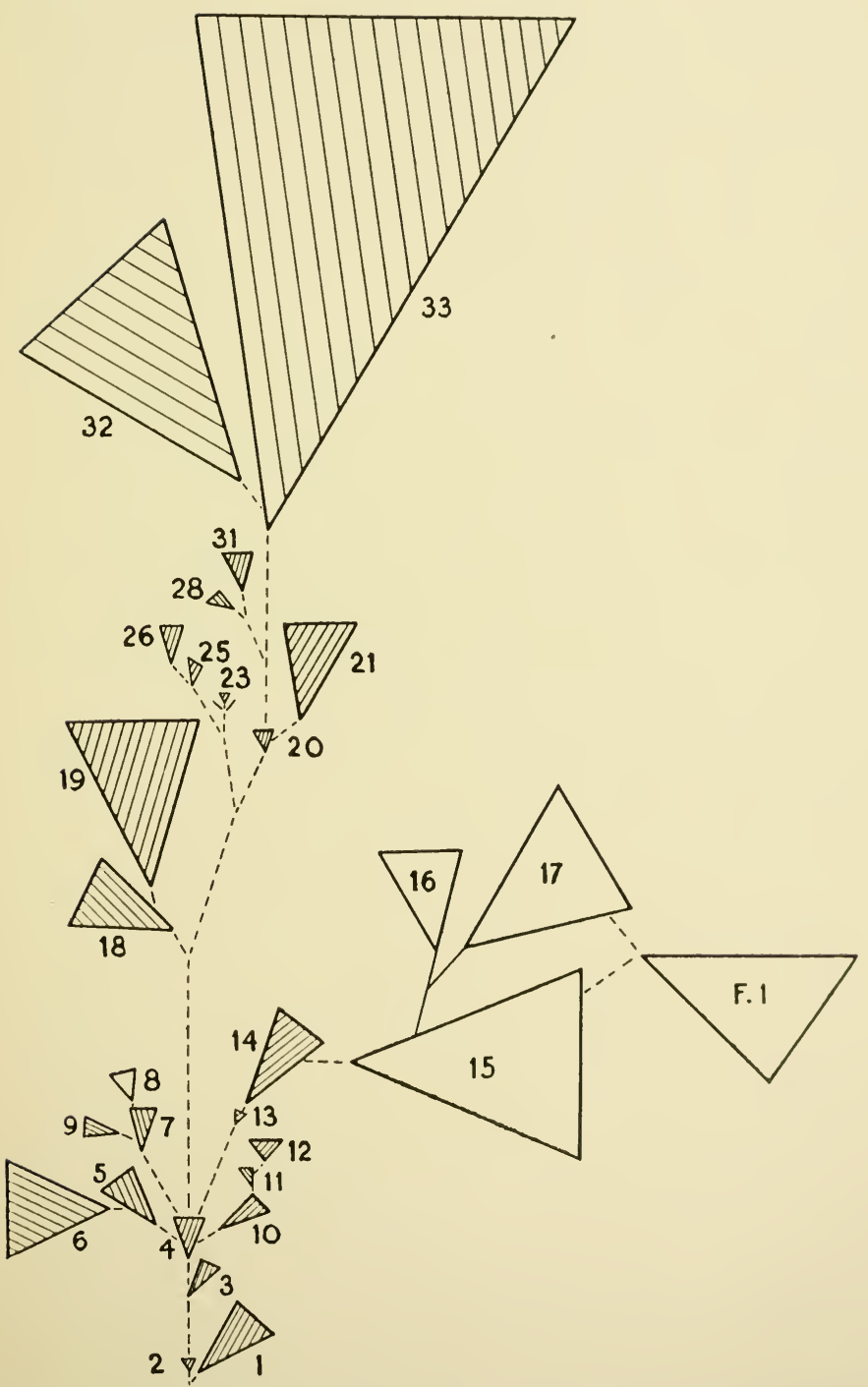

FIG. 7.- Schematic arrangement of the vegetable kingdom; for explanation see p. 38 . 
relationship of the phyla. The classes represented by the shaded areas are those that are chlorophyll bearing, while the classes of fungi are left unshaded. Classes I-7 and 9-1 4 are aquatic, being the Alge; I 8 and 19 are respectively Mosses and Liverworts; 20-26 inclusive are Ferns and Fern allies; 28 are Cycads; 3 I are Conifers; 32 Monocotyledons; and 33 Dicotyledons. Class $S$ is the Phycomyceter; I 5 the Ascomyceter: i6 the Teliosporea; and $I_{7}$ the Basidiomyceter; while F.I. represents the Fungi Imperfecti.

The classes omitted $(22,24,27,29$ and 30) are chiefly fossil plants, so that their relative size cannot be shown on the table, which aims to show the relative number of species now existent. 


\section{CHAPTER II.}

FUNGOID DISEASES OF CEREAIS AND GRASSES.

I. Smuts. Class: 'Telosporeæ; Order: UsTILAGINALES ; Family: UstilaginaCE 2.

Smut is also known to the farmer as dust brand, chimney sweeper, sleck, slean, etc.

The cause of all smut of the small grains was previously set down to a single species to which the name Ustilago carbo was given : recent research has shown that the smut of different genera of grasses is caused chiefly by species of Ustilago, but in many cases of other genera as well. The economically important forms, however, are mostly species of Ustilago.

(a) Oat Smut (Ustilago Avena). ${ }^{1}$ - Much damage is caused in certain districts by this fungus.

Symptoms.-- Plants which up to the time of the appearance of the ear have looked quite healthy are found to produce, instead of grain, a brownish black powder, which is easily carried and distributed by the wind, leaving nothing but the bare straw at harvest time.

${ }^{1}$ A closely related species, $U$. lavis, has been found along with this species, the spores of which are perfectly smooth. 
Cause.-Examined under the microscope the above brown powder is found to consist of myriads of spores (chlamydospores or teliospores) of the fungus Ustilago Avence.

Each spore is rounded and has two coats, but the spores are free from the fishy odour which accom-

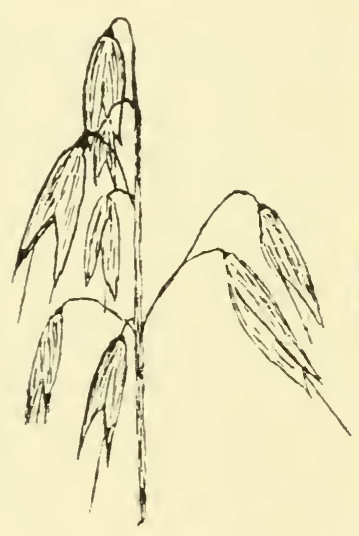

A

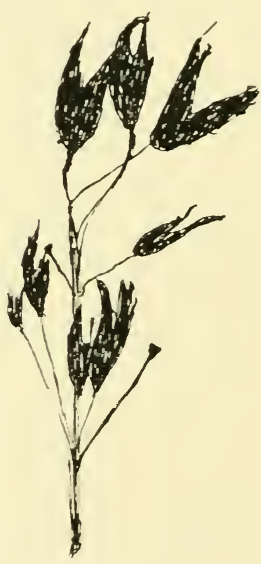

B

Fig. 8.-Oat smut (Ustilago Avena) : (A) Portion of healthy ear of oats; (B) Portion of smutted ear; notice that the spikelets are very irregular in shape and blackened with the spores of the fungus.

panies the spores of bunt (see p. 47). The spores germinate readily in water, and dung heaps also form a suitable medium for growth.

Since the spores are distributed before harvest, some are blown on to the healthy ears, but no development takes place until the grain is sown the following spring. The grain and the spore germin- 


\section{DISEASES OF CEREAIS AND GRASSLS 4I}

ate together, the former producing a young plant, the latter a short hypha, the pro-mycelium (see Fig. 9, A) and conidia.

The conidia, on germination, form a germ tube capable of penetrating the tissues of the oat plant, but only at this young stage. The plant suffers no apparent effect from the intruder. Hecke, however,
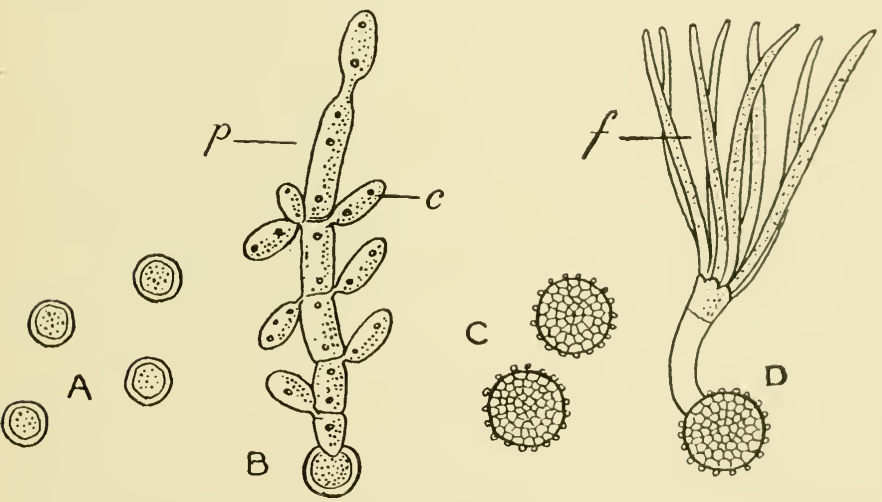

FIG. 9.-(A) spores of Ustilago Avenc: (B) a spore germinating in nutritive solution; notice the septate pro-mycelium $(p)$ with the oral conidia $(c)$ at the side; (C) spores of Tilletia Tritici: (I)) the same germinating, producing a short pro-mycelium with a wisp of long conidia $(f)$ at the end. (Magnified about 300 times. After Brefeld.)

has shown that the ear may be infected by moistening with water containing smut spores ("Journal B. of Agr.," Feb., I906. Vol. I2, page 699). The hyphe grow actively in the growing point of the stem, and when the ear begins to be formed, they break up to form the sooty powder (i.e. the spores), thus revealing the presence of the parasite, 
Preventive Measures.-

I. Copper solutions, p. 28.

2. Hot water treatment, p. 29.

3. Formaldehyde treatment, p. 32. This is the best of all.

(b) Barley Smuts.-(1) Naked or loose smut (Ustilago muda) $=U$. Hordei (Bref.) ; (2) covered smut (Ustilago Jensenii (Rostr.)).

(1) Naked Smut.--Of the two this is the more common in Great Britain. The spores are dispersed before harvest. Infection takes place through the flowers, the mycelium entering the ovary, where the grains become infected. The diseased grain produces a plant in whose growing point the fungus progresses, destroying the ear when formed.

Prevention.-Treatment, to be effective, must destroy the fungus within the grains without injuring the vitality of the latter, this is possible with the modified hot-water treatment of Jensen. (See further note under wheat smut.)

(2) Covered Smut.-Here the bulk of the spores is not distributed before harvest. The ear may remain within the upper part of the sheath practically intact, except that instead of the healthy grain, smut spores are formed and surrounded by the fertile glumes. Infection takes place at the seedling stage from spores adhering to the grain, hence treatment of the grain with fungicides is effective.

Prevention.- Treat the grain prior to sowing 
with $\frac{1}{2}$ per cent solution of copper sulphate (see page 29) or with formaldehyde solution (p. 32).

(c) Wheat Smut (Ustilago Tritici).

This is sometimes called loose smut, and must not be confused with bunt (stinking smut) (see p. 45). The mycelium uses up not only the nutriment intended for the development of the grain, but the chaff is also attacked.

Prevention.-Difficult to combat, as copper or formaldehyde solutions are apparently ineffective. It can, however, be completely controlled by the use of the modified hot water treatment (p. 30). Inasmuch as this is a slow processnot more than 8-10 bushels of grain can be treated in a day,-it is suggested that sufficient grain be treated each year to plant a plot of two or three acres from which the seed for next year's sowing may be obtained. This seed plot should be planted away from other fields of wheat so as to avoid infection of the seed at blossoming time by the spores carried by the wind from such other fields.

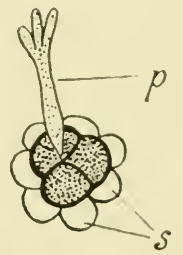

Fig, Io.-A ball of spores of Urocystis oc. culta (rye smut). In the centre the dark fertile spores, one of which has sent out a short pro-mycelium $(\phi)$; these are surrounded by sterile spores (s). (Highly magnified.)

(d) Rye Smut (Urocystis occulta).

This is seen in the form of grey stripes, mostly on the stem but also on the leaves, which latter burst and expose the black spores (Fig. IO). 
The germ tube is said to be only able to enter the plant in the young stage.

Prevention.-

I. Steep seed in copper solution (p. 28).

2. Jensen's hot water treatment (p. 29).

Results from the treatment of the seed are by no means uniform.

Note. - I. Rye smut caused by Ustilago Secalis is very rare. It destroys the whole ear.

2. Urocystis Agropyri forms black bands of spores on couch grass, hungarian forage grass, etc.

(e) Maize Smut (Ustilago Maydis).

None of the fungi above described cause such malformations as U. Maydis. Not only the grain but every part of the plant is attacked. First white wrinkled patches appear, which swell, and later burst, thus liberating the spores. It is definitely known that the plant can be infected at a late stage of growth as well as in youth.

Preventice Measures.-

I. Sow grain from fields not badly infected.

2. Remove by hand, and burn, the smut masses before they burst.

3. Avoid, as far as possible, planting maize on fields where smut was serious the preceding year.

(f) Brome Smut (Ustilago bromiora).

While the above fungus may check the growth of the undesirable grass (Bromus mollis) to some extent, in those meadows where it is found in abundance, 
still this smut, like the rest, must be looked upon as an undesirable quantity. The amount of the brown powder (smut spores), shed on the grass and hay, causes the latter to become so black as to make it doubtful whether it is wise to feed such hay to stock. The glumes-chaff-are said not to be attacked, but the writer has seen whole areas of smutted brome grass with the glumes also attacked; perhaps this was caused by a variety of the above species. Instead of the grass seed a mass of spores is produced.

Preventive Measures. -

I. Soft Brome (Bromus mollis) is an undesirable annual plant, therefore pasture for a year or two, and keep from seeding.

2. Apply manures to improve the quality of the herbage.

(g) Tall Oat Grass Smut (Ustilago perennans)

This is widespread and of frequent occurrence. The mycelium rests over winter in the rhizome, i.e. below the surface.

Prevention. - Hot water treatment of the seed (p. 29).

II. Bunt (Tilletia Tritici ${ }^{1}$ ). Class: 'TelosrOREa: Order: Ustilaginales ; Family: TilLETIACE\&.

Bunt, or, as it is sometimes called, stinking

${ }^{1}$ Kühn describes a species T. lavis, which causes bunted grains, and differs from $T$. Tritici only in having smooth spores. 
smut, is one of the most objectionable diseases of cereals. It destroys a number of ears, and at thrash-

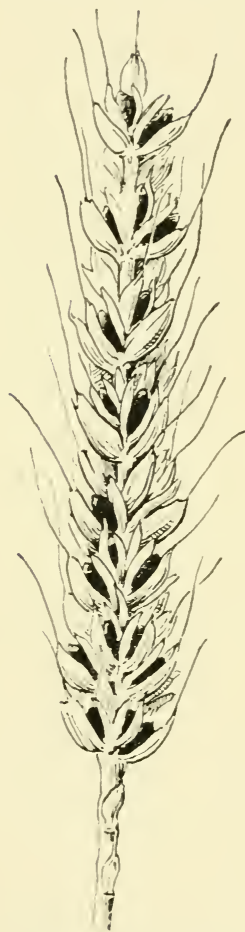

FIG. II.-A diseased ear of wheat showing the dark coloured bunted grains enclosed within the glumes (somewhat diagrammatic). ing the remaining healthy grains become covered with the black spores, thus spoiling the taste and colour of the flour made therefrom ; while the straw and chaff are made distasteful to stock.

Symptoms.- It is only with difficulty that bunted ears can be distinguished from healthy ones at harvest time. The bunted ears are broader, the glumes more open, and the grains have a greyish colour (see Fig. I I). The opening of the glumes is due to the increased breadth of the bunted grain encased within (Fig. 1 2, B). Sometimes the grains are cracked; this reveals the inner contents, viz. a black mass of spores of the fungus. These spores have a strong fishy odour due to the presence of trimethylamine.

Canse.-The bunted grains are caused by the formation of the spores of the fungus ( $T$. Tritici) from mycelium which had entered the wheat plant in the early stage and grown up with it. 
The spores are fairly large and round, with a reticulated surface (see Fig. 9, C and D).

According to Kühn the germ tube from both the primary and the secondary conidia is able to enter the host plant, grow within its tissues, and, at the time of grain formation, produce bunted ears.
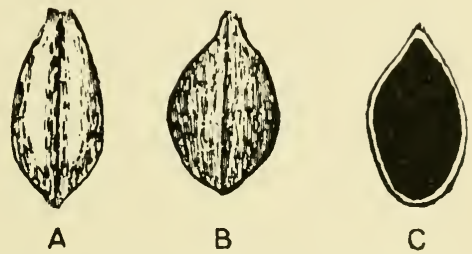

Fig. 12.-Grains of wheat: (A) shows the shape of the healthy grain; (B) shape of a bunted grain; note how much broader it is than the healthy one; (C) longitudinal section of a bunted grain showing the black mass of bunt spores enclosed.

Some of the differences between smut and bunt are enumerated below :-

\section{Smut.}

Spores distributed before harvest.

Spores small, smooth.

Spores odourless.

coats 


\section{SMUT.}

mycelium with oval conidia at the side (Fig. 9, B).

Conidia multiply by No budding of conidia.
BUNT.

a group at the end (Fig. 9, C).

budding.

Preantive Measures.-

I. Treat with copper solution (see p. $2 S$ ).

2. Hot water treatment (see p. 29).

3. Treat with formaldehyde solution, which is the. most satisfactory and is easily applied (see p. 32).

Note.-Various species of Tillctic attack the leaves and fruits of other cultivated plants, but space does not allow of their description.

III. "Rusts." Class: 'Teliosiones: ; Order : Uredinales.

Enoimous damage is done annually to our wheat crops by the ravages of the rust fungi; and this notwithstanding that there are varieties of wheat on the market which are practically resistant to the disease. It is earnestly to be hoped that the efforts of the biologist at the School of Agriculture, Cambridge University, to obtain, by crossing, rustresisting varieties possessed of that "strength" which the miller desires, will be crowned with success. Since the above was written a variety (Little Joss) having these qualities has been obtained.

A few of the most important rusts are described below. 
(a) Rust and Mildew of Wheat (Puccinia graminis).

Many varieties of wheat are attacked.

Symptoms. - The leaves of attacked plants turn a pale yellow colour in early summer, and later elongated reddish-orange spots appear on the leaf, sheath, and the stem. These spots turn a much darker colour in the late summer (see Fig. I 3 ).

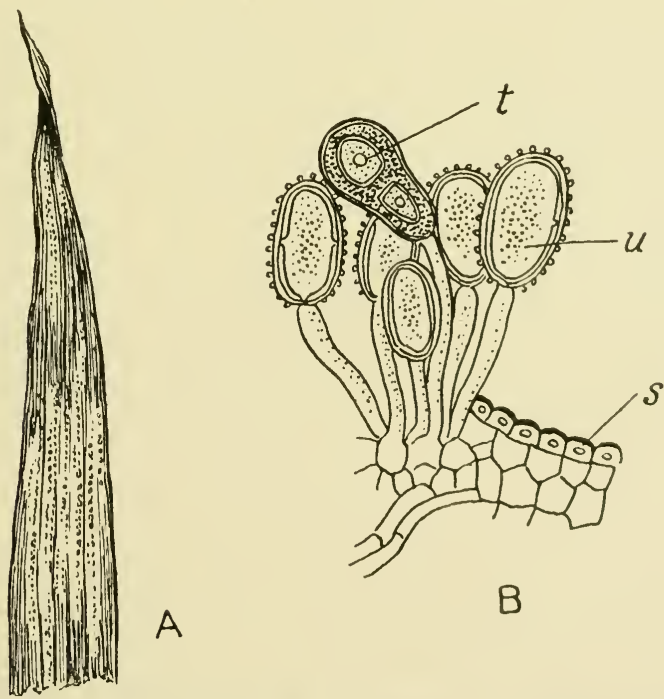

FIG. I3.-Rust of wheat (Puccinia graminis): (A) showing the small pustules covering the wheat leaf; (B) section through a pustule from (A); (u) uredospore; $(t)$ teleutospore; $(s)$ surface cell of wheat leaf.

Cause.-This disease is caused by the fungus Puccinia graminis, which has a very interesting, but complex, life history ; for it apparently usually 
utilizes but probably does not require two host plants on which to complete its life cycle (see p. 5I).

The reddish-yellow pustules above mentioned are due to the fungal threads breaking through the epidermis and bearing the orange-coloured spores called uredospores (Fig. I3, B). These are the summer spores ; they are thin walled, light coloured, and one celled, and are easily carried by the wind to healthy wheat plants, on the leaves, leaf sheaths, and stems of which they germinate. They send out a germ tube which enters and ramifies within the tissues, branches and rebranches, finally breaking through the surface and producing the yellow pustules.

The darkening of the pustules is due to the formation of another kind of spore-teleutospore or teliospore-from the same mycelium (see Fig. I 3, B). These teleutospores are longish oval, two celled, and have a thick outer wall. They are borne on a stalk about the same length as the spore, and rest over winter. In the spring they germinate, each cell sending out a hyphal thread which branches at the tip and forms four sterigmata, on each of which a conidium (sporidium or basidiospore) appears. This basidiospore appears to be incapable of infecting the wheat plant, but it is able to penetrate the leaf of the barberry (Berberis vulgaris), develop within, and in a short time produce small flask-shaped bodies called spermogonia on the upper surface of the leaf. 
These contain spores, but their use is not definitely known. On the under side of the leaf, at the same time, cup-like openings appear, called xcidia. These acidia are seen as reddish-yellow raised patches, and they are filled with accidiospores. 'The recidiospores are roundish cells with smooth outer coats; they retain their power of growth for a short time only. They may germinate on the barberry leaf, but the germ tube does not enter; if, however, they are carried by the wind to the stem or the leaf sheath of the wheat plant, the germ tube readily enters the inner tissues, develops, and in the course of 8 to Io days aerial hyphx break through the surface and bear at the tip the uredospores; which in mass appear as red pustules. These uredospores are readily carried by the wind to healthy wheat plants, thus causing infection.

Experiments in America have demonstrated that, in that country at least, the rust is able to survive the winter on the over-wintering wheat plants, producing an abundance of uredospores in the spring, so that the presence of the barberry is not an essential for the maintenance of the disease. Indeed it has been found that sometimes the mycelium remains alive in the seed, and so infects the new crop.

NOTE.-According to Erikson there are six biological varieties of $P$. graminis, each having its æcidial stage on the barberry.

For preventive measures see p. 54 . 
(b) Golden or Spring Rust (Puccinia glumarum). (Fig. I 4, C and D). This rust was previously considered as a variety of $P$. mbigo vera, but Erikson, as a result of inoculation experiments, considers it a distinct species with several biological varieties.

The roundish uredospores appear on the leaves of grasses, in the form of lemon to cadmium coloured irregular pustules or sori. These sori may spread longitudinally, forming ultimately yellow linear markings. The teleutospores are sparse, and in the form of fine brownish-black stripes.

The teleutospores are set on short stalks and germinate in the autumn of their formation. The pro-mycelium is of a bright yellow colour-this distinguishes it from Puccinia dispersa-which colour disappears on the formation of the sporidia.

The recidial stage is unknown.

Although abundant in spring, the damage done is not serious.

For preventive measures see p. 54 .

(c) Brown Rust (Puccinia mbigo vera = Puccimia straminis, Fuckel ; Puccinia dispersa, Erikson).

This rust is found chiefly on the leaves of rye, wheat, barley, and various grasses, in the form of rust-red, roundish, scattered patches. The uredospores are much rounder than those of $P$.graminis.

The teleutospores are present in the same pustule, in fact, spring from the same mycelium; they are 
not so dark in colour as those of $P$. graminis, have a much shorter stalk, and are not covered with a crown of paraphyses or hairs.

The xecidia are found on the bugloss, but are not essential, for uredospores may be found on young wheat and rye plants in the autumn, and the mycelium is undoubtedly able to rest there over winter, as well as in various grasses, and on account of this is most difficult to combat.

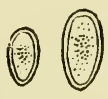

A

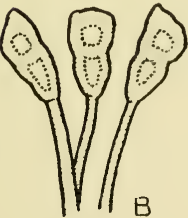

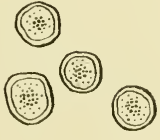

C

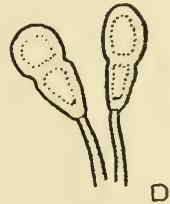

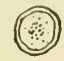

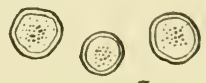

E

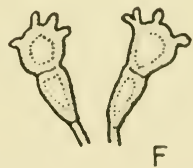

Fig. I4.-(A) uredospores of Plucinia graminis: (B) teleutospores of Pucinia graminis; (C) uredospores of Puccinia glumarum: (D) teleutospores of Puccinia glumarum; (E) uredospores of Puccinia coronata; (F) teleutospores of Puccinia coronata: notice the crow'n of spiney projections at the end. (All highly magnified.)

For preventive measures see p. 54.

(d) Barley Rust (Puccinia simplex; Korn).

Attacks barley, but the damage is only slight. The teleutospores are mostly one celled.

(e) Crown Rust of Oats and Grasses (Puccinia coronata, Corda). 
By inoculation experiments Klebahn has shown that there are two distinct species, viz. :-

(i) Puccinia coronata - found on many grasses, especially Dactylis glomerata (cocksfoot) and Festuca silvatica, a variety of sheep's fescue.

(ii) Puccinia coronifera-which occurs on various grasses, and also on oats, but not on wheat and barley.

The uredospores of $P$. coronifera are found on the upper surface of the leaf of oat plants, in the form of small orange coloured sori. The teleutospores are in the form of minute greyish black spots, and are characterized by a crown of spines around the end cell; hence the name "crown rust" (see Fig. I 4, F). "Apparently they are not able to germinate until the spring.

The accidiospores are found on the buckthorn.

Preventive Measures. - Owing to the diversity of spore formation, and to the mycelium being within the plant, the various rust diseases are most difficult to combat. Spraying and pickling of the grain are quite out of the question, hence any recommendations must of necessity be of a general character.

I. Avoid heavy dressings of nitrate of soda, give small amounts along with superphosphate.

2. Select varieties which show least susceptibility 
to rust and still maintain the other essential characters, e.g. Little Joss.

3. Sow autumn grain somewhat late, and put in spring sown early.

4. Drain the land.

5. Climatic conditions have their influence, but are beyond control.

NoTE.-A large number of rust fungi attack various garden plants and would have been described had space allowed.

IV. Ergot (Claviceps purpurea). Class: Ascomycetea ; Order: Pyrenomycetales.

Found on cereals and grasses, but especially common on rye and rye grass. This fungus prevents healthy development of the grain, and the sclerotia contain poisonous substances-ergotin and cornutin-which are said to be injurious to stock.

Symptoms. - Ergotted ears have large black bodies-the sclerotia - taking the place of some of the grains, and projecting beyond the other parts, making diseased ears easily recognizable (Fig. I $5, \mathrm{~A})$.

Cause. - The above sclerotia are the resting bodies of the fungus Claviceps purpurea which has taken up its abode in the ear, thus causing the disease. In early winter they fall to the ground, and can withstand drought and cold. In spring they germinate ${ }^{1}$ in the soil, giving rise to numerous

${ }^{1}$ May be collected and germinated in the laboratory in moist sand. 
mushroom-like outgrowths called stromata (see Fig. I 5, B) with violet stalks and yellow heads.

These heads contain numerous flask-like bodies - perithecia-with the narrow part pointing outwards (see Fig. I 5, C and D) and containing numerous asci (spore cases). Each ascus encloses
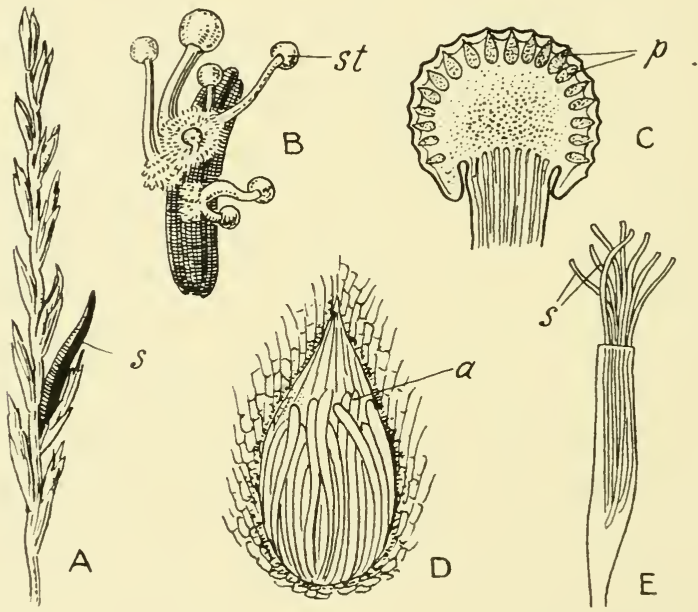

FIG. 15.-(A) Rye grass affected with Claviceps purpurea; (s) sclerotium; (B) germination of a sclerotium (st) stroma; (C) longitudinal section through a stroma showing the perithecia $(p)$ containing asci; (D) perithecium more highly magnified showing the position of the asci $(a) ;(E)$ an ascus very highly magnified; $(s)$ the ascospores. (After Tulasne.)

eight long, slender ascospores (Fig. I 5, E). When the ascospores are carried by the wind to the base of the floret of the host plant, they send out a germ tube which enters the ovary and produces at the same time a mycelium externally bearing numerous conidia. A sugary substance is secreted 
by this mycelium-sometimes called the honey dew stage; this entices bees, which carry away, on their legs, the conidia to healthy grass flowers, where they readily germinate, enter the ovary, form honey dew and conidia, and, like the first mycelium, when the food supply becomes exhausted, i.e. towards autumn, form the sclerotia by interlacing and repeated branching. The shrivelled ovary may often be found at the end of the sclerotium.

\section{Preventive Measures. -}

I. Collect as many sclerotia as possible and sell to the chemist.

2. Do not allow grass in pastures and waste places to seed.

3. Cut, collect, and burn grass parcels which are ergotted.

4. Drain land well and improve the herbage so that it will be well eaten down.

5. Sow seeds free from ergot.

V. Smother Fungus of Grasses (Iipichloe typhina). Class: Asconycetes; Order: PyкелoMYCETALLS.

This is frequently found in abundance on many grasses, especially meadow foxtail (Hlopcomms pratensis) and cocksfoot (Dactylis glomerata), and although not a serious pest, it is said to be injurious to horses if eaten in abundance.

Symptoms. - The upper leaf sheath becomes sur- 
rounded by an ochre-coloured collar, or muff-like growth, consisting of a felt of fungus hyphæ. These hyphæ penetrate the sheath and stem, filling up the spaces between the two. The part is quite hard when cut through.

Cause. - The collar-like growth is caused by the fungus Epichloe typhina, the hyphae of which encircle and penetrate the sheath and stem. The colour of the collar darkens with age.

Preventive Measures. - Very difficult to combat, little beyond cutting down and destroying attacked grass can be recommended.

VI. Wheat and Grass Mildew (Erysiphe graminis). Class: Ascomycetea; Order: PeriSPORIALES.

Wheat suffers to a larger extent than grasses.

Symptoms.-During the summer months the leaves of grasses and wheat become covered with greyish-brown, irregular, felt-like patches on the upper surface, consisting of the mycelium of the fungus Erysiphe graminis. Short hypha arise, bearing conidia in chains (see Fig. I6, C).

Cause.-The cause of the peculiar grey covering is the presence of the mycelium of Erysiphe. The oval spores are readily carried in the atmosphere to the surface of the leaves of healthy plants, where they germinate and set up new centres of infection.

In autumn small dark-coloured bodies, visible to the naked eye, appear on the same threads that 
bore the conidia; these are the perithecia containing asci. They remain attached to the leaves until the spring, when they liberate the ascospores, which on germination again produce the disease. But even failing these perithecia, the fungus may be found on the wheat plant in winter, where it undoubtedly can remain until the spring.

\section{Preventive Measures.} - Unfortunately very

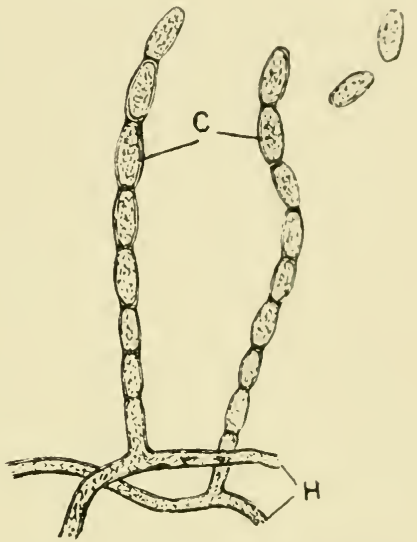

FIG. I6.-Portion of the hyphie ; (H) of Erysiphe graminis bearing the oval conidia (C) in chains. (Highly magnified.)

little can be done.

I. Small areas may be dusted with flowers of sulphur, but this is too costly and impracticable for field crops.

2. Spring sowing is said to be an advantage.

VII. Discoloration Due to Funcil.

(a) Browning of Wheat Leaves. - This browning of the leaves is of somewhat frequent occurrence on the Continent.

Symptoms. - Appears in spring on winter sown wheat : the leaves turning somewhat yellow at first. and later more to the brown, while finally they dry up. On the brown surface small black spots may be 
found, by means of a pocket lens; these are the fruit capsules of the fungi present.

Cause.-According to Frank the eight fungi enumerated below, which are much alike externally, contribute to the cause of this disease: sometimes singly, sometimes several of them being concerned.

(1) Septoria gramineum, Desm.

(2) Septoria briosiana, Morini.

(3) Septoria glumarum, Pass.

(4) Septoria avena, Frank.

(5) Ascochyta graminicola, Sacc.

(6) Phoma Hennebergii, Kühn.

(7) Leptospharia Tritici, Pass.

(8) Spharella exitialis, Morini.

Some of the above fungi may also be concerned in the blackening of the grain.

Little can be done in the way of prevention.

(b) Leaf Brown of Barley (Helminthosporium gramineum, Erik.).

This disease is very prevalent on the leaves of barley on the Continent, and many crops in England suffer from the same cause. Potter has shown that it is the cause of "deaf ears" in barley.

- Symptoms. - Elongated, dark, brownish-olive patches with yellowish circumferences appear on the leaf while it is still green; these spread, especially lengthwise, destroying the tissues until the whole leaf becomes discoloured, dried, and split up into ribbons. The under leaves are attacked first, and 
may be very badly infested before the ear appears. In bad attacks the ear never gets out of the sheath. Cause.-The appearance of this disease is often due indirectly to adverse weather conditions weakening the plant, but directly to the fungus H. gramineum, which penetrates and destroys the tissues. How winter is passed over, and how infection takes place the following spring; is not known.

Preventive Measures.-No definite means of prevention are known. Spraying with different furgicides has been carried out at Cambridge, but the results are not very promising.

(c) Blackening of Straw and Black-ended Barlcy (Cladosporium herbarmm).

İungi Imperfecti; Order: Moniluales.

With humid weather conditions the straw of wheat, oats, and barley becomes a black or greyish colour. In some cases the grain also becomes blackened, hence the term "black-ended barley" (see Fig. I 7) ; such barley being
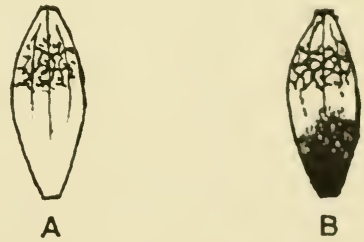

FIG. I7.-Black-ended barley: (A) healthy.grain; (13) blackended grain, caused hy the fungus Cladosporimm horbarum. considerably reduced in value.

Cause.-With moist conditions the mycelium of Cladosporium herbarum grows abundantly on and in vegetable matter. This fungus is widespread. 
It causes the blackening of the moist cloths of the cheese-maker.

Preventive Measures.-On account of the widespread nature of the fungus and the uncontrollability of the weather, little can be done to check this ubiquitous pest. Crops in moist districts should be cut early, and thrashed grain should be stored perfectly dry.

(d) Leaf Brown of Oats (Helminthosporium. teres, Sacc.).

Fungi Imperfecti; Order: Moniliales.

Resembles in many respects barley browning, except that infection commences at the tip of the leaf, spreading downwards. The conidiophores are single, the conidia smaller and have a greenish "nuance".

A species of Helminthosporinm causes a blight on the leaves of maize.

(e) Grasses.-Small, raised, well-defined, oval black spots, resembling in size and appearance " fly droppings," are formed on the leaf blades of cocksfoot and other grasses by the fungus Phyllachora graminis. These black spots contain the perithecia with their spores enclosed. Not of a serious nature.

NOTE.-Space will not permit of a description of other minor fungus diseases of grasses and cereals.

For diseases of plants coming under this section caused by insects, see "Farm and Carden Insect Pests," by Somerville. M.M. of Co. 


\section{CHAPTER III.}

FUNGOID DISEASES OF LEGUMINOUS PLANTS.

(Peas, Beans, etc.)

I. Milnews. -
(a) Mildew.
(b) Mildew (false).
(c) Mildew (downy).

(a) Mildew (Erysiphe Martii). ${ }^{1}$ Class: Ascomycetea ; Order: Perisporiales.

This fungus attacks various species of Pisum, Lathyrus, Vicia, and Trifolium: especially towards the end of summer, doing considerable harm.

Symptoms.-First observed as a snow-white covering on the leaves while the latter are still green, later this woolly covering of fungus mycelium turns a dirty grey, and the leaf assumes a paleyellow sickly colour.

Cause.-Microscopic examination of a leaf with the above symptoms shows that the cause is the presence of the fungus $E$. Martii (not to be confused with false mildew, p. 64). This fungus is

1 This fungus also appears on certain cruciferous plants. 
an obligate parasite ${ }^{1}$; when its spores germinate on the surface of the leaf, the germ tube branches and rebranches, forming the wool-like growth. The mycelium does not enter the plant, but special organs called haustoria (see p. 5) draw nutriment from the host for the fungus. The spores are formed in chains from short branches of the mycelium, in a similar manner to E.graminis (Fig. I6). When carried by the wind to the surface of healthy leaves they readily germinate, ${ }^{1}$ thereby setting up new centres of infection. Later small, brownish bodies about the size of a pin's head are formed on the mycelium on the surface of the wilted dying leaves. These little bodies gradually become black; they are the perithecia containing asci in which the ascospores are formed and enclosed. The ascospores are set free and carried by the wind to healthy young plants in the spring.

(b) False Mildew (Peronospora Trifoliorum and Peronosporavicia). Class: Phycomycetea; Order : Peronosporales.

Peronospora Trifoliorum causes false mildew of clover and lucerne especially, but is also found on other plants.

$P$. vicice causes false mildew on various leguminous plants, particularly vetches and peas. Both

${ }^{1}$ The spores may be germinated on certain artificial media, but the germ tube soon dies, in fact it is, up to the present, impossible to grow the fungus as a saprophyte. 
spread in dry weather as well as wet, and cause considerable damage.

Symptoms.-Similar outwardly to those given under true mildew above. A greyish white covering of mycelium is seen on the under surface of the leaf, on the stem, and on the leaf stalk; pinkishgrey spots appearing when the spores are formed. The attacked plants turn yellow and thrive badly.

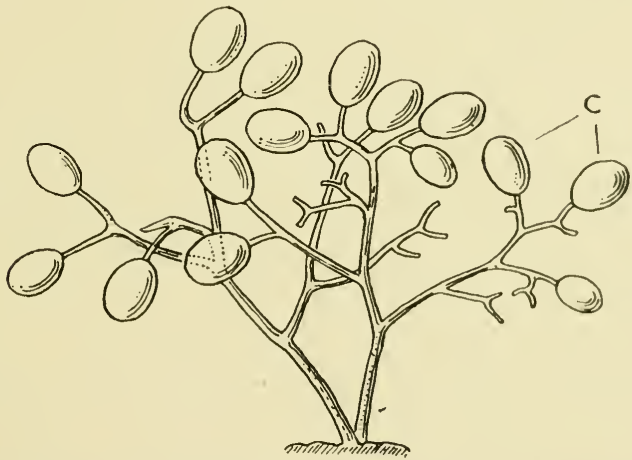

Fig. I8.-False mildew of vetches-conidiophore of Peronosfora V'icice growing through a breathing pore; (C) the oval conidia. (Highly magnified.) (After Tubeuf.)

Cause. - The yellowish colour is due to the fungus hypha ramifying within the tissue of the attacked plant and depriving it of part of its nourishment (compare Erysiphe, p. 63). Tree-like conidiophores grow through the breathing pores of the leaf, and the conidia are formed at their tips ; these are able to germinate immediately, and when transported may start new disease areas. Resting spores with smooth coats are formed inside the diseased 
tissue as a result of sexual union; they are called oospores, and germinate the following spring.

The above description holds good for $P$. vicice, except that its oospores have a reticulate thickened outer wall.

(c) Downy Mildew (Phytophthora Phaseoli). Class : Phycomycetex; Order : Peronosporales.

Damage to beans and peas may be serious, other plants are also attacked. Greyish-white patches of mycelium appear on the leaves, stems, and pods ; from this mycelium conidiophores arise which bear spores in a similar manner to Phytophthora infestans (see Fig. 2 I, B, p. 76). The mycelium also penetrates the inner tissue, from which it derives its nourishment.

Prevention of the different Mildews.-

I. Mow infected clover crops to save what remains of them.

2. Spray with Bordeaux Mixture, repeating every fortnight.

3. Washes of potassium sulphide are very effectual, but too expensive.

4. Burn badly diseased parts.

5. For attacks of Erysiphe on small areas dust with flowers of sulphur.

6. Drain the land well, for first attacks are usually in moist places.

II. Rusts. Class: Teliosporeæ; Order: UreDINALES. 
(a) Clover (Uromyces ${ }^{1}$ apiculatus, Schrot.; $U$. Trifolii, Hed.).-Common on red, white, and alsike clover. On white clover uredo-, teleuto- and aecidiospores are formed, while on the other two, uredo- and teleutospores only. The mycelium causes thickening and wrinkling of the stalk and veins of the leaf.

(b) Beans (U. phaseolormm).-All three kinds of spores are formed; haricot and scarlet rumner beans are chiefly attacked.

(c) Peas (U. pisi).-Uredospores and teleutospores are formed on different species of Pisum, Lathyrus and Vicia, aecidiospores on the spurge (Euphorbia).

(d) Lucerne (U. striatus, Schroeter).-Causes rust spots on various species of Medicago, due to the formation of uredo- and teleutospores. The aecidiospores are formed in the spurge.

Proventive Measures.-

I. Burning of infested areas is recommended in each case but is impracticable.

2. Sow early.

3. Keep down such weeds as spurge.

II I. Sclerotiun Disease or Cloversi (Silerotinia. Trifoliomum). Class: Asconrcetes: Order: PliziZALES.

This disease causes more harm to our clover

${ }^{1}$ The genus Uromyces differs from P'ucinic in having one-celled teleutospores. 
crops than is generally imagined, for only when it breaks out as an epidemic is any notice taken of it.

Symptoms.-The attacked plants turn yellowish without any visible sign of the cause, and gradually die off. On examination of the dead parts, especially the root and part of the stem at, or near, the ground surface, the sclerotia may be seen as small black button-like growths (Fig. I 9, A, sc).
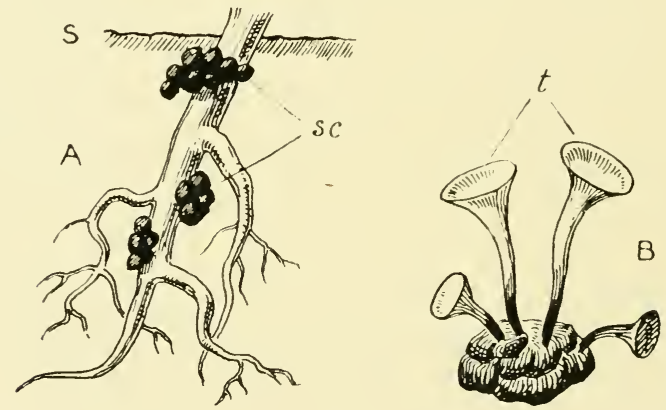

Fig. I9.-Sclerotium disease of clover: (A) portion of clover root with sclerotia (sc) attached; (B) a sclerotium germinating; $(t)$ the trumpet-shaped stroma containing the spores; $(s)$ the soil level. (After Frank.)

Causc.-The cause of the plants dying is the presence in their tissues of the fungus Sclerotinia Trifolionm. This mycelium absorbs its food supply from the clover plant, thereby causing gradual starvation. The plant ultimately dies and shrivels up, and the fungus, in order to prepare for emergencies, forms sclerotia. These sclerotia can rest over winter, in fact are capable of growth after being kept dry for two or three years. Under 
favourable conditions they germinate the following summer, giving rise to yellowish-brown trumpetshaped growths (see Fig. I 9, B). Inside the trumpet shaped openings are numerous asci standing erect and side by side. The ascospores are capable of immediate germination, but their germ tube is unable to enter direct and live parasitically, until strengthened for a time by saprophytic nourishment.

Preventive Measures. -

I. Collect and destroy attacked plants.

2. Do not grow clover too often on the same land.

IV. Spot Disease of Peas (Ascochyta pisi).

Fungi Imperfecti; Order: SpHaropsinales.

Peas, possibly lucerne and other leguminous plants, suffer from this disease.

Symptoms.-Brown spots appear on the pods (see Fig. 20, s), leaves, and on the stems, at first near the ground, but later on all parts. These diseased areas on the stem often penetrate to the water-conducting tissues and cause the plant to dic with symptoms of a "wilt disease". On the discoloured areas, minute black dots (the picnidia or spore cases of the fungus) appear. On the pod, the spot may penetrate from one side to the other, destroying the enclosed seed, or the seed may be infected without killing it, so that some (only a low percentage) will germinate, thus carrying the disease over to the following year. 
Cause.-The disease is caused by the parasitic fungus Ascochyta pisi, which destroys the tissues, producing discoloured spots. The disease is transmitted in infected seeds (see Fig. 20, $c$ and $b$ ), and also in the diseased stems and leaves, if these are allowed to remain on the ground over winter.
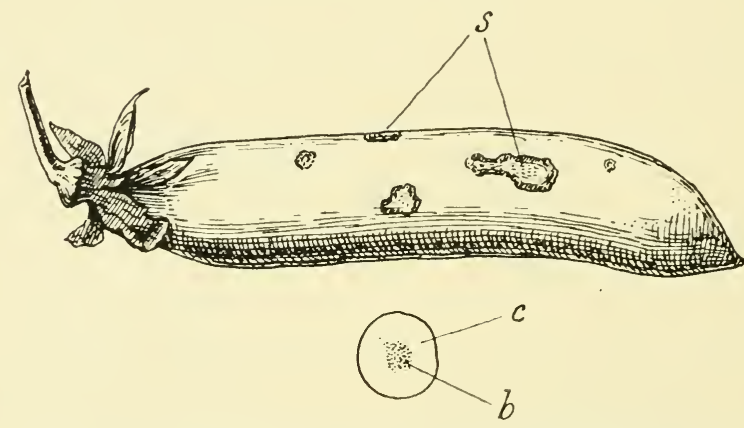

FIG. 20.--Pod of pea suffering from Spot Disease (Ascochyta pisi) (s); below a cotyledon (half of a pea) $(c)$ with diseased centre $(d)$.

Preventive Measures.-

I. Sow seeds from healthy plants, or from fields not affected; if suspicious of the seed, sow only plump unspotted seeds.

2. Do not grow peas two years in succession on the same field.

${ }^{1}$ Beans, particularly haricots, suffer from a disease known as anthracnose, and caused by Colletotrichum lindemuthianum. This causes brown spots on the pods, seeds, and also on the stem of seedling plants, as well as brown lines along the leaf veins. It is not easily controlled, but the same methods should be adopted as for the spot disease of peas. 
3. Remove and burn all plants at the close of the season.

V. Violet Root Rot of Lucerne (Rhizoctonia violacea).-Fungi Imperfecti.

According to Kühn, various other plants are attacked, including potatoes, red clover, beet, mangels, carrots, etc., but apparently cereals are not susceptible.

Symptoms. - Yellow patches appear in the crop quite suddenly. Plants uprooted from such patches will be found to have the roots covered with a brownish-violet growth. In a bad case the stems may also be attacked.

Cause. - The facultative parasite Rhizoctonia violacea is responsible for the yellow appearance of the crop and violet covering of the roots. It spreads its mycelium over the tap and side roots, some of the threads penetrating the inner tissue, thereby robbing the plant of nourishment, and finally killing the roots and causing the falling of the plants.

So far no spore formation has been noticed, but sclerotia may be found. The mycelium can spread from plant to plant. The fungus doubtless belongs to the Basidiomy'cetes.

Preventive Measures. -

I. The fungus grows best on sour soil, therefore sweetening the land by liming checks its growth.

2. For the same reason drain land well. 
3. Keep down weeds which may act as food when other plants are lacking.

4. Dig over diseased spots deeply and apply carbon-bisulphide.

5. Grow cereals on the land for a year or two.

6. Remove all diseased parts where this is practicable.

(See " Journal of the Board of Agriculture," Vol. I 2, No. I I. Tubeuf, p. 2 I9. Minnesota Plant Diseases, p. 329. Massee, p. 345.)

VI. Other Diseases of Lucerne and Clover.

(a) Disease of Crown of Roots (Urophlyctis alfalf e ). Class : Phycomycetee; Family : CladoCHYTRIDIACE A.

The above fungus has caused much harm to the lucerne crops on the Continent, and was identified by Salmon on lucerne sent to him, which was grown in the Eastern Counties. 'The fungus causes wart-like outgrowths at the crown of the roots, which consist of hypertrophied tissue. In these swellings there are minute pits in which the spores of the fungus are found.

Very little is known as yet as to the method of infection, and in consequence preventive measures cannot be recommended.

(b) Diseased seeds (Macrosporium sarcinaforme). - Fungi Imperfecti; Order : Moniliales.

This fungus, which has been known for some time to cause considerable damage to the leaves 
and stems of lucerne plants and clover, has been found inside the seed and causing non-germination. Such diseased seed is somewhat shrunk and wrinkled, and much darker in colour than healthy seed.

The mode of infection is not known, but in all probability it spreads from the stem and leaves to the seed.

Precaution.-Buy only seed well harvested in warm dry districts, and see that it is plump and bright in colour.

(c) Leaf Spots. - I. Phyllachora Trifolii, Pers.: 2. Pseudopeziza Trifolii, Fuckel ; 3. Pseudopeziza medicaginis, Lib.

I. Phyllachora Trifolii-Causes black shining spots on the leaves of clover, especially red clover. These spots are larger than those caused by Pseudo. Trifolii. No satisfactory preventive is known.

2. Psendopeziza Trifolii. - Causes yellowishbrown spots on the leaves of clovers, especially red clover. Serious damage may be caused by this fungus. Preventive measures of no avail.

3. Psendopeziza medicaginis is responsible: for the yellow spots on lucerne leaves, and in the U.S.A. has caused considerable loss. Frequent cutting has been found to prevent spore formation, and in this way tends to check the spread of the disease. 
Dodder (Cuscuta Trifolii). - This is a parasitic flowering plant, not a fungus. Its yellowish stringlike stem winds around and entangles the clover plant and is sometimes mistaken for a fungus. It is rootless, but is able to obtain a supply of food through the agency of haustoria (suckers) from the clover plant, causing as a result reduced growth of the host and finally death.

Preventive Measures.-

I. See that samples of clover seed are free from the seeds of dodder.

2. Dig up attacked patches. 


\section{CHAPTER IV.}

\section{FUNGOID DISEASES OF POTATOES.}

I. Potato Disease (Phytophthora infestans). Class: Phycomyceteat Order: Peronosporales.

It is also known as potato blight, rot, demic, etc., all being names given to the disease caused by Phytophthora infestans. It was first noticed in the United States about the year I840, and in Great Britain in ${ }^{8} 43$. Serious damage was not done

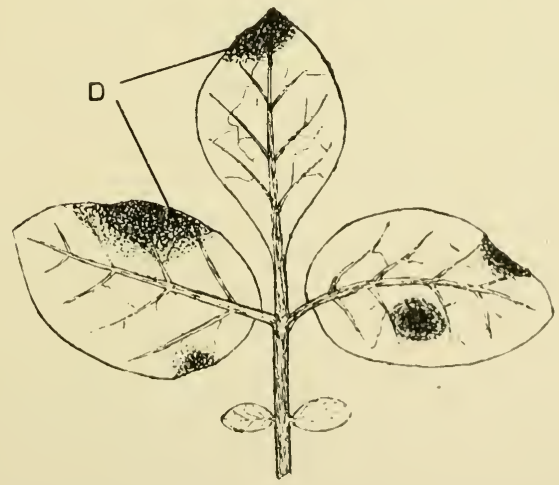

FIG. 2I (A).-Part of a potato leaf with the dark disease spots caused by Phytophthora infestans.

until the wet summer of 1845 , when practically the whole area under potatoes suffered. 
Symptoms. - The first sign of the disease is the appearance of yellowish-brown thumb-like marks on the leaves, which, as digestion and decomposition

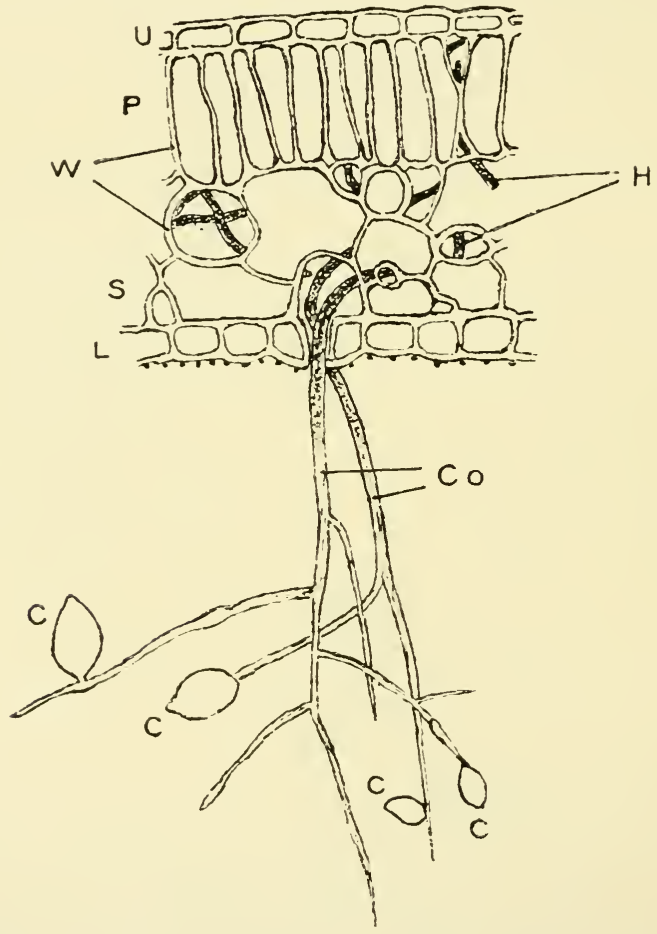

FIr. 2I (B).-Cross-section through a leaf at one of the diseased spots (D); (U) upper and (L) lower side of leaf ; $(\mathrm{P})$ palisade tissue; (S) spongy tissue ; (W) the wall of the plant cell; $(\mathrm{H})$ the hypha of the fungus; (Co) the conidiophores; (C, C, C, C) the conidia.

proceed, become darker in colour (Fig. 2I, A). Around the outer edge of these spots a ring of white felt-like growth may be seen in very moist weather on the under side of the leaf (Fig. 2 I, B). 
Cause.-Examination of the above felted growth, microscopically, shows it to be a plantation-like growth of the fungus Phytophthora infestans, bearing conidia at the tips and sides of the branches (Fig. 2 I, B). These conidia are easily detached and carried away by the wind; if they fall on a dry surface no further development takes place. Should they fall on the moist surface of the leaf of

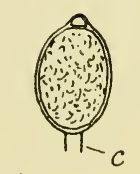

A

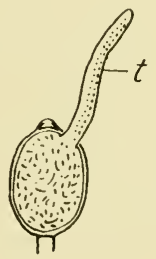

B

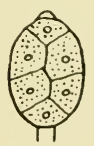

C

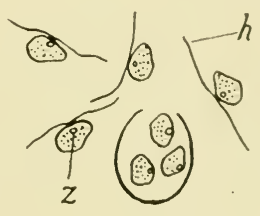

D

Fiv. 22.- "Potato Disease" (Phytophthora infestans): $(\Lambda)$ A conidium with part of conidiophore (c) attached; (B) conidium germinating, having produced a germ tube $(t)$; (C) a sporangium showing the division into cells; (D) a sporangium germinating, some of the zoospores $(z)$ are already liberated; notice the cilia or hairs $(h)$ by means of which they swim about.

a potato plant, their protoplasm divides, and five to ten zoospores are formed which subsequently become liberated. Each zoospore consists of a minute speck of protoplasm ; bearing two cilia (hairs) by means of which it is able to swim for a time. It soon comes to rest, the cilia are resorbed, and germination commences (see Fig. 22, A, B, C, and D). The germ tube produced either enters a stoma, or digests and penetrates the cell wall of the leaf or stem on which it is found. 
Once inside the plant, the germ tube branches and ramifies in all directions, piercing the cell wall and causing death of the infected tissues. The hyphie in the leaf send out aerial branches through the stomata bearing conidia (Fig. 2I, B), which become detached, carried in the air to healthy plants, and hence the rapid spread of the disease, for all this goes on in the course of a few days. Ultimately the whole haulm succumbs, Phytophthora being assisted in the later stages of decomposition by other fungi. Infection of the tubers by the spread of the fungus down the stem to the tubers is said not to occur, but takes place, due to the conidia, or zoospores produced in them, being washed down through the soil to the young tubers.

The infected tubers may decay at once, or if the infection is but slight and the soil not too wet, they may not decay until storage, especially if the temperature be high and the circulation of air limited. Such decaying tubers serve as centres of infection, and the whole of the tubers in the immediate area may become rotten. If stored in a cool dry place with free circulation of air the slightly diseased tubers survive, but when planted they either decay outright, or give rise to short completely diseased shoots a few inches high, which bear huge crops of conidia of the fungus in their short life, and so infect the healthy plants. The diseased tubers show slightly sunken patches (some- 
times called nailheads) varying in size, which when the epidermis is scraped have a purple colour ; such a tuber, if cut and placed in a moist warm atmosphere, will develop an abundance of the fungus hyphæ from these spots.

The oospores (resting spores) are claimed by W. G. Smith to have been found by him in 1875 , but the matter remained in doubt in many quarters. Recently, however, Dr. G. P. Clinton' at the Connecticut Agricultural Station, and others following his methods, have succeeded in obtaining oggonia and oospores in pure artificial cultures of the fungus ; Pethybridge ${ }^{2}$ has shown that they are identical with the oospores formed by $P$. erythroseptica, which causes pink rot of potatoes. It is still uncertain whether these are ordinarily produced in nature, but the fact that the disease appears to be equally as bad (sometimes worse) on newly brokenup. land indicates that the disease is not usually carried over winter as oospores in the dead leaves, etc.

Preventive Measures.-

I. Plant sound seed.

2. Plant seed of the more resistant varieties.

3. Earth up well so as to prevent the conidia from being washed down to the tubers.

${ }^{1}$ Clinton, Reports Connecticut Exp. Station (1911), and earlier reports (1905-10).

2 Pethybridge and Murphy, Sc. Pro. Royal Dublin Society, Vol. XIII. (N.S.), No. 36, March, I9I3. 
4. Do not plant too closely, but allow light and air to enter : crowded plants keep moist longer and are more likely to suffer from the disease.

5. Spray with Bordeaux Mixture (see p. 25).

6. Collect and burn diseased haulms where this is practicable.

7. Boil diseased tubers prior to feeding.

S. Cutting off the tops has been found to reduce the disease in some cases, but results in a decrease in the crop.

9. Do not dig tubers which are to be stored until at least ten days after the death of the haulms, so that tubers already infected may have a chance to decay, while the danger of infection of the tubers on digging is to a great extent avoided.

II. Ротатo Leaf Curl (Macrosporimm solani, E. et M.). ${ }^{1} \quad$ Fungi Imperfecti.

NOTE. - This disease must not be confused with the "Leaf Roll " (Blattrollkrankheit) or the "Curly Dwarf" or "Curly Leaf" (Kriuselkranklieit) so prevalent on the Continent, which are not caused by a fungus, but are due to a physiological derangement.

This disease is more prevalent in the United States (where it is called early blight) and in Continental Europe than in Great Britain, though during dry seasons more harm is done to our own crops than is generally imagined.

Symptoms. - Brown irregular patches, marked by concentric zones, are found on the leaves, without

${ }^{1}$ This has been claimed to form its conidia in chains under cultural conditions and would then be called Altcrnaria solani. 
any visible appearance of the fungus (Fig. 23, A) ; later, dark patches consisting of masses of conidia are seen. These conidia are dark coloured, irregular in form, and multicellular.
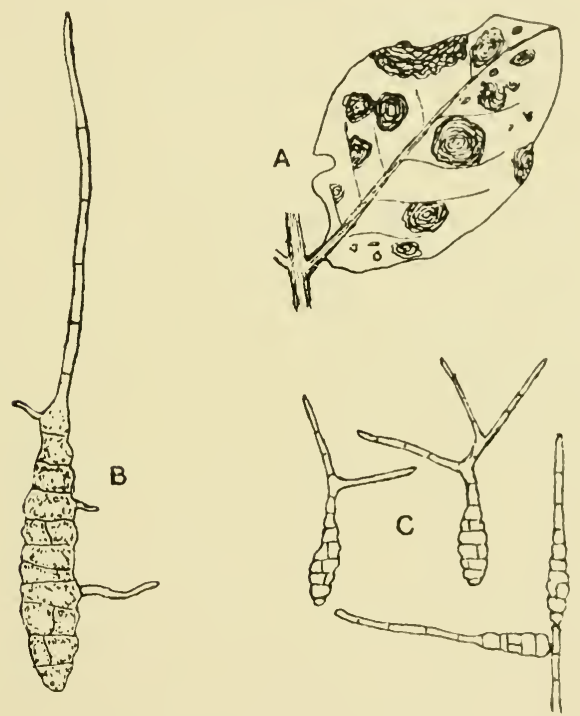

FIG. 23.-(A) Potato leaflet suffering from Leaf Curl; notice the irregular spots with concentric rings; (B) club-shaped septate spore of Macrosporium solani with germ tubes from some of the cells; (C) peculiar forms of spores; (A) slightly reduced; (B and C) magnified; (B and C) after Jones.

Cause. - The cause of the disease is the presence of the fungus $M$. solani. Its mycelium, which is dark in colour, destroys the leaf tissue, sometimes resulting in curling, and forms later, large conidia on simple, or branched, conidiophores. (Fig. 23 , $\mathrm{B}$ and $\mathrm{C}$.) 


\section{Preventive Measures. -}

I. Spray early with Bordeaux Mixture (p. 25).

2. Keep the plants in good growing condition by suitable manurial dressings.

III. Black Leg or Stem Rot (Bacillusphytophthorus ${ }^{1}$ ).-Sometimes whole areas (75 per cent of the crop) become completely rotten, the late application of farmyard manure and moist warm weather favouring the spread of the attack. Cereals have been proved to be immune.

Symptoms.-Seen in June and July, attacked plants becoming wilted and discoloured from below upwards, the leaves and the stems below and above ground being affected. Usually spreads quickly from one plant to another, and the sets may become rotten. The chief lesions occur in the vicinity of the ground level, in the form of blackened cankerlike areas, hence the name "black leg".

Cause.-Though various fungi are found in the tissues, the primary cause of the disease is a small parasitic organism, Bacillus phytophthorns, which destroys the living tissues of the plant; it is undoubtedly assisted in the later stages by such fungi as Botrytis cinerea, MIncor and Fusarium species, and others.

1 This does not belong to the true fungi. A disease is described by Harrison, the symptoms of which resemble the above, under the name of Bacillus solanisaprus (Cent. Blatt f. Bact., Bd. I7, No. I-2). 


\section{Preventive Measures.}

I. Grow cereals on the land for a few years.

2. Apply the farmyard manure in autumn.

3. Avoid forcing artificial manures.

4. Soak the sets in Bordeaux Mixture prior to planting.

5. Treat the tubers before planting with formaldehyde solution (p. 32).

NoTE. - Not all plants with some of the symptoms described above are necessarily affected with the disease, as serious local unfavourable conditions may bring about similar symptoms. However, if these symptoms show on a number of plants, especially those of a particular variety or from a special source, care should be taken to prevent loss by following the preventive measures suggested.

IV. Leaf Roll and Curly Divarf. - These are the names given respectively to two diseases of a serious nature, known in Germany by the names "Blattrollkrankheit" and "Kräuselkrankheit". Both are so-called " physiological diseases," not being caused by parasitic organisms. They are transmitted by planting tubers from plants having the disease. The disease appears, apparently spontaneously, over large areas, affecting certain varieties and leaving others untouched, possibly climatic conditions are partly responsible.

Symptoms. - (a) Leaf Roll. The leaves are rolled upwards on the midrib, and yellowish, or often reddish or purplish in colour. 'The plants remain small and no tubers are formed, or at most only a cluster of small ones at the base of the stem. Tubers 
are often, though not always, produced on the stem above ground.

(b) Curly Dwarf (or Curly Leaf). The plants are dwarfed, particularly the vascular parts, i.e. stems, branches, petioles, and midrib, and consequently the leaves are crinkled and curled (downward), the few tubers produced are small.

Preventive Measures.-

I. Plant tubers only from healthy fields.

2. Practise crop rotation.

3. Keep the ground well cultivated and manured, and by spraying or other means avoid weakening of the stock by disease.

V. American Potato Scab (Oospora scabies). Fungu Imperfecti.

Prevalent on light sandy soils, causing a decrease in the value of the sample, though they may be of excellent quality otherwise. Of frequent occurrence in Continental Europe and in the United States. There has been much controversy regarding the cause of this disease, but the conclusions of Thaxter are now generally accepted for the American scab.

Symptoms. - Instead of the smooth or slightly roughened surface, attacked potatoes have a very coarse appearance, being covered externally with numerous rounded excrescences, caused by the abnormal production of cork, giving the whole a reddish-brown, rusty, scabbed appearance.

Cause.-The cause of the American scab is the 
presence of a minute fungus-Oospora scabies, but whether this same fungus is the cause of the scab in Europe is still open to doubt, as owing to the name scab being assigned indiscriminately to so many skin diseases a considerable amount of confusion exists.

Lime and alkaline manures are credited with producing scab, but while these substances maly result in a form of scab or in an apparent increase of the attack, the true cause must be looked for in some parasitic fungus, either similar to, or identical with, that described by Thaxter.

Whatever the true nature of the disease may be, the preventive measures recommended by the American investigators, and enumerated below, might with advantage be adopted in this country.

\section{Preventive Measures. -}

1. Steep tubers to be used for planting in mercuric chloricle solution (p. $3 \mathrm{I}$ ).

2. Plant tubers free from scab.

3. Give infested land a rest from the crop.

4. Do not plant the disinfected tubers in land where potatoes or beets have developed scal in previous years.

VI. Wart Disease OR BLack SCab (C'moysophlyctis endobiotica)-(Synchytrimm endobioticum. Percival). Class : Phycomycetese; Order : ChytriDIALES.

This disease is common in Continental Europe, 
from whence, in all probability, our land became infected. Schilberszky noted and described it in I 896. It was noticed in Great Britain in I 999 , and is now very prevalent in Lancashire and the Midlands.

Symptoms.-On certain patches, or in extreme cases on the whole of the potato, wart-like outgrow ths appear (see Fig. 24, A). As a rule, they are at the "rose end" only, and are brownish in colour.
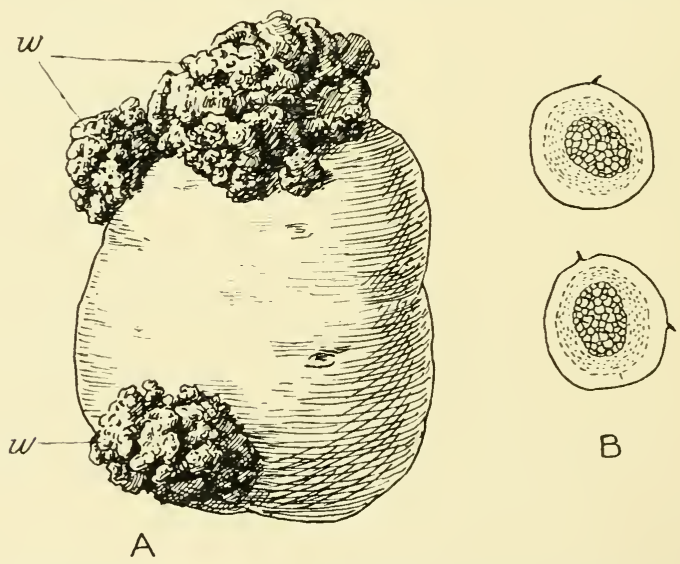

B

FIG. 24.-(A) Tubers with warty outgrowths $(w)$ caused by the wart disease fungus (Synchitrium endobioticum); (B) two sporangia (resting stage) with thick walls.

Cause.-The cause of the abnormal growth is to be found in a low type of fungus, $C$. cndobiotica, which gains entrance to the tuber at the "eyes," and once inside it stimulates the tissues resulting in the wartlike growths. Numerous swarm spores are produced in these excrescences, which are capable of 
propagating the disease. Under favourable conditions of growth the resting stage (sporangium, Fig. 24, B) of the fungus is produced, whereby the winter is brooded over, for apparently there is no growth in the tuber after lifting.

Preventive Measures.-

1. Dust the "seed" potatoes with flowers of sulphur before planting.

2. Plant sets free from the disease.

3. Grow disease-resistant varieties, e.g. Langworthy.

4. Avoid planting on land where the disease has occurred.

(See "Highland and Agr. Soc. Journal," I903, p. 3I2.)

Wart Disease is scheduled as a notifiable disease and must be reported at once to the Secretary, Board of Agriculture and Fisheries, Whitehall Place, London, S.W.

VII. Corky Scab or Powdery Scab (Spongospori subterranea) occurs in the form of powdery irregular patches on the surface of potatoes. It may be of a serious nature where potatoes are grown frequently on the same land; especially during a wet season. The disease is spread by planting affected tubers. It has been declared a notifiable disease, and cases must be reported without delay to the Secretary, Board of Agriculture and Fisheries, Whitehall Place, London, S. W. 
VIII. DRY ROT (Fusarium solani). Fungi Imperfecti; Order: Moniliales.

Some ten to fifteen species of Fusarium are capable of causing rot of potato tubers, some causing wet, others dry rot. The name Fusarium solani has probably been applied rather indiscriminately to all of these. Though the fungus is widespread, the damage caused is small compared to that caused by some of the other fungi.

Symptoms. - Shrivelling up of the contents of the potato, causing cavities on the surface, in which a whitish grey felted mass of mycelium may be seen.

Cause.-The mycelium noted above is that of Fusarium solani, which grows in and between the cells, destroying the cell tissue but leaving the starch grains unattacked, though some of them may, at the later stages, have the mycelium penetrating them. Entrance to the potato usually takes place through some wound, but Wehmer has shown that the hyphæ are also capable of entering potatoes which are perfectly intact.

The hyphæ are long and fine with cross walls. The spores are very characteristic; being long, slender, pointed, cresent shaped, and multicellular.

Note.-Phellomyces sclerotiophorus also causes a dry rot. Here again the starch grains are very little changed.

Prevention.-Unfortunately the fungus is so widespread that little can be done. The "pies" may be opened and the diseased tubers picked out. 
IX. Wet Rot.-This may cause serious damarge where potatoes are stored in a wet state. Potatoes grown on wet low-lying land often suffer, and if flooded for a few days frequently become reduced to a mass of pulp.

Symptoms. - In the "pies" individual potatoes, or a mass of them, are found with the inner contents a mass of a pulp-like consistency-hence the name wet rot-and smelling strongly of butyric acid.

Cause. - The organisms causing this disease are not true fungi, two species of bacteria being largely responsible, viz. Clostridium butyricum and Bacillus mesenteroides. These multiply in the intercellular spaces, dissolve the cell wall, and in a very short time reduce the potato to a pulp, the starch grains remaining intact. The reaction of the inside at the early stages is acid, but later becomes alkaline. Clostridium butyricum flourishes only without air, i.e. anaerobic. Kramer isolated an aerobic organism, i.e. one which grows in the presence of air, producing butyric acid and capable of causing wet rot when inoculated on wounded or unwounded potatoes,

How far these organisms are assisted in their attack by other fungi is not known, but certain it is that they are not alone in their ravages.

Note. - A species of Rhizoctonic causes wet rot, and also attacks the starch grains. 


\section{Preventive Measures.-}

I. Turn potatoes in the "pie" frequently and remove any rotten tubers.

2. Rotation of crops (doubtful).

3. Drain the land well.

4. Store potatoes in a perfectly dry condition.

Pethybridge ("Pro. Roy. Dub. Soc.," Vol. XIII, No. 35, I9I3, and Vol. XIV, No. Io, 1914) describes a "wet" rot for which he suggests the name pink rot and which is caused by Phytophthora erythroseptica. Apparently the disease is only of a serious nature on land that has been successively cropped with potatoes; further observations and inquiries may show that the disease is more widespread and the damage greater than is at present thought to be the case.

$\mathrm{X}$. Siotted Tubers, - Like the markings on the leaf, those on the tuber are almost legion in number; classification is difficult and not very satisfactory. The exact cause of their appearance is in many cases obscure.

(a) Blotches or Pimples (Spicaria nivea).--Fungi Imperfecti; Order: Moniliales.

Much loss has been caused, especially in Scotland and East Anglia, during the past few years, by a peculiar disease in the form of pimples or blotches. The author first noticed it on the variety "Evergood," which is particularly susceptible, but many or all of the other varieties are attacked. It 
appears to be worst on land that has been recently limed.

Symptoms, - The spots may be seen at lifting time, but are particularly noticeable after storing. They occur particularly at the "rose" end of the potato and are black or brownish-black in colour, $\frac{1}{8}$ to $\frac{1}{4}$ inch diameter, with the circumference sunken and the centre raised. They penetrate the potato $\frac{1}{8}$ inch only (i.e. skin deep), the inner contents of the tuber remaining apparently healthy. Not only are the spots unsightly and reduce the market value ; but if there are many of them near the "eyes," the tubers are quite useless as sets. ${ }^{1}$

Cause.-Microscopic examination of sections through the spots readily reveals the presence of fungal threads (Fig. 25, A), and the culture media inoculated from the inside of the pimples develop, without exception, a growth of Spicaria mivea (Fig. $25, \mathrm{~B})$ and sometimes other fungi are present. All attempts to produce the spots, however, by inoculation of healthy tubers with S. nivea, or the other fungi, have failed. Carruthers comes to the conclusion that the fungi present merely enter the lenticels as saprophytes, and cause the blackening of the tissue. The matter is worthy of further investigation.

1 The author considers this disease the cause of the great irregularity in many crops of "Evergood," the fungus destroying the eyes. He saw at one farm in Lincolnshire in the spring of 1904 two to four tons of "deaf sets" which had, fortunately, been noticed and picked out before planting. 


\section{Precautions.-}

I. Examine sets carefully prior to planting, and reject all with blotches.

2. Do not plant potatoes immediately after liming.

3. Shun those varieties which are most susceptible to the attack - - Evergood," "Flourball," etc.

4. Examine "Evergood" seed carefully, and reject any "blind" sets.

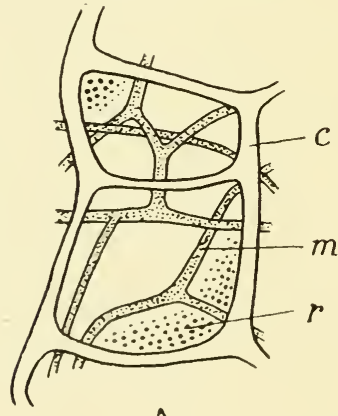

A

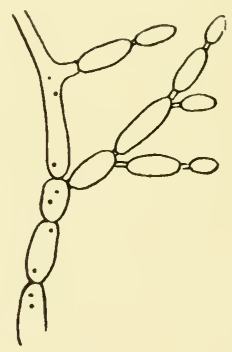

B

FIG. 25--(Spicaria nivca): (A) microscopic section through one of the pimples on the potato showing the fungus mycelium $(m)$ inside the cells; $(c)$ the cell wall; $(r)$ the remains of digested starch grains; (B) portion of the hyphæ of Spicaria nivea showing the formation of the spores in chains. (Highly magnified.)

(b) Black irregular markings.-Caused by Khizoctonia. Here the skin is perfectly intact and the blackness can be rubbed or washed off.

(c) Some scurf diseases, not of a serious nature, are said to be due to mechanical disturbances.

(d) The lenticels are often seen in the form of small 
raised meal-like markings, and are sometimes mistaken for disease spots. The potatoes are, however, perfectly healthy.

(e) Rust-like specks or streaks are sometimes found inside otherwise sound tubers, hence the names "streak," "sprain". The cause is not definitely known. No fungus has as yet been found within; it does not spread in the "pies," and is apparently not contagious. Weather and soil conditions are thought to be responsible, but further research may reveal the presence of some organism within the tissues.

NOTE.-For insect pests attacking this group see "Farm and Garden Insect Pests," by Somerville. M.M. \& Co. 


\section{CHAPTER V.}

FUNGOID DISEASES OF CRUCIFERS.

I. Finger-and-Toe (Plasmodiophora brassica). Class: Myxomycetes (Slime Fungi).

This disease is also known as anbury and club root. It is widespread, and attacks many kinds of cultivated and wild crucifers, but cabbages and turnips in particular.

Symptoms. - Abnormal tuberous swellings ${ }^{1}$ (see Fig. 26) appear of no fixed form, which gradually become rotten and give off a very disagreeable smell. While this is going on, the leaves lose their waxy bloom and healthy green appearance, turning yellow and stunted in growth. Finally the whole root and leaves may become one mass of putrefaction.

Cause.-Woronin first found the slime fungus Plasmodiophora brassica which causes this disease. Sections through the swollen parts, examined microscopically, show that certain of the cells are

${ }^{1}$ Not to be confused with the swellings caused by the turnip gall weevil (Ceutorhynihus sulcicollis). 
abnormally enlarged and filled with a slimy substance which is the protoplasm of the fungus. After feeding in the cell for a time, this foreig n protoplasm (plasmodium) breaks up and forms numerous spores within, and filling up, the enlarged cells (see Fig. 27). These spores are liberated in millions in the decaying mass.

Under favourable conditions the cell wall of the spore ruptures and a small mass of protoplasm is liberated bearing a cilium (hairlike growth) by means of which it is able to move about. Shortly this is resorbed and subsequent movement takes place in a creeping manner, i.e. by the small portion of proto-

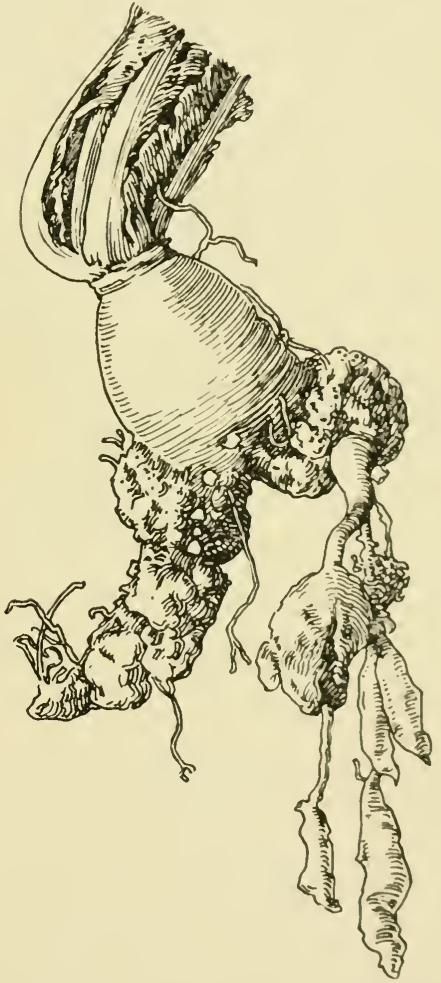

FIG. 26.-Turnip showing the peculiar finger-and-toe-like swellings on the roots caused by Plasmodiopliora brassica; the upper swellings are in an advanced state of decay. (After Northumberland C.C.) plasm changing its shape. In this stage it is able to enter a cruciferous plant, exactly how and where 
is not known, but probably via the root hairs. Once inside, food is absorbed from the cell contents, irritation is set up, and the abnormal cells result in
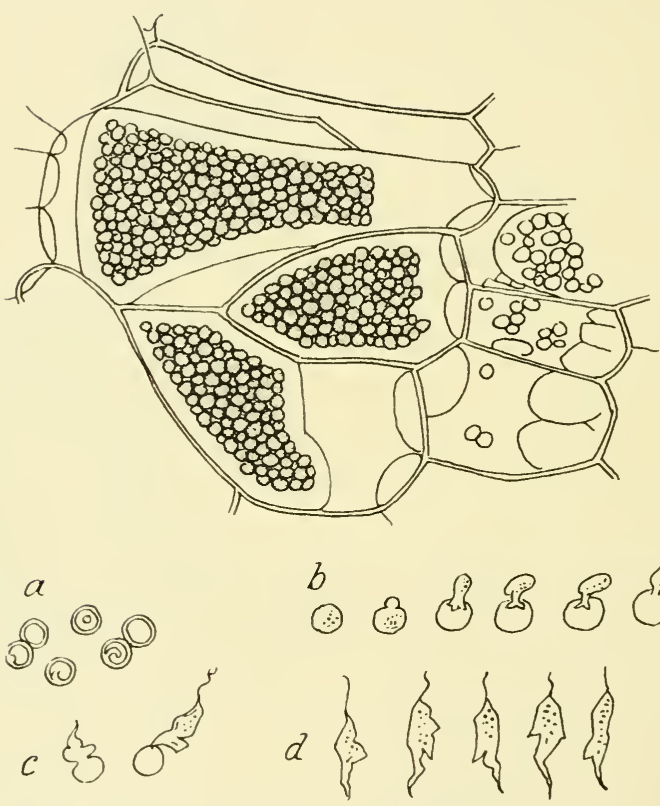

FIG. 27.-Finger-and-Toe Disease (Plasmodiophora brassica). Showing giant cells in portions of tissue taken from the abnormal growths on roots; note that the protoplasm of the fungus has broken up into a mass of spores; $(a)$ spores more highly magnified; $(b)$ "germination " of spores; $(c)$ the ciliated portion of naked protoplasm emerging; (d) the naked protoplasm (plasmodium) liberated. (After Woronin.)

consequence. Portions of protoplasm are capable of piercing the cell wall and entering previously healthy cells.

How long the spores retain their power of germination, how winter is passed, and how the small 
protoplasmic mass enters the plant, are points awaiting solution.

\section{Preventive Measures.-}

I. Do not grow cruciferous plants too often on the same land.

2. Remove diseased roots from the field.

3. Do not spread refuse from the turnip heaps on land where turnips, etc, are to be grown.

4. Disease is most prevalent on sour land: sweeten such land by drainage, and by the application of about 2 tons or more of lime per acre, immediately the turnip crop is removed, and in extra quantities where the disease was worst. Gas lime is of little value for the purpose.

5. Keep down cruciferous weeds-charlock, shepherd's purse, etc.

6. Avoid the use of acid manures, e.g. superphosphate.

7. Prevent as far as possible the transportation of soil from infected to healthy areas.

8. Do not raise seedlings for transplanting on land that is susceptible to the disease.

9. Do not plant clubbed seedlings.

II. Damping OFF (Pythimm de bayamum). Class: Phycompetex; Order: Saproleginiles.

A troublesome disease to the gardener, most cruciferous plants being affected, but especially mustard and cress. It is not confined to crucifers only. 
Symptoms.-Where seedlings are too thick and too moist, they turn yellow in patches; and, due to a weakened place in the stem, at the soil level, fall over; the attack spreading with amazing rapidity.

Cause.-Indirectly the cause is too thick seeding and too much moisture; directly the fungus Pythium de Baryanum is the culprit. Its branched nonseptate hyphæ grow within the plant and draw

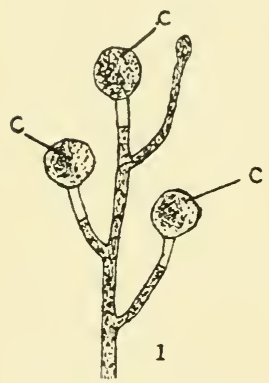

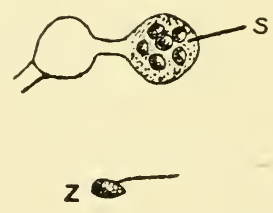

2

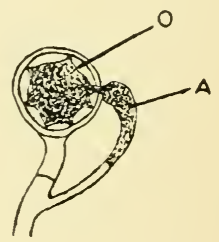

3

FIG. 28.-Pythium de Baryanum: (x) Portion of mycelium bearing conidia (C) at the ends of the branches; (2) Sporangium with zoospores enclosed $(Z)$, a zoospore with a cilium or hair; (3) Antheridium and Oogonium; after uniting a resting spore, called an oospore, is formed. (After De Bary.)

nourishment from the contents of the cells; resulting in the weakening of the part and consequent falling over. Later the hyphæ grow on the outside and may reach short distances to healthy plants.

Preventive Measures.-

I. Do not sow too thickly.

2. Do not shade seedlings too much or keep them too moist. 
3. Do not grow seedlings on infected soil, but regulate the moisture in the soil and air so as to have an optimum for plant growth without an excess which favours fungoid growth.

4. On first appearance remove diseased patch and a coronet of the surrounding healthy plants, and burn.

5. Deep cultivation has been recommended, as it is said to bury the oospores.

6. Steeping the seed in various solutions has been suggested, but seeing that the fungus is capable of living as a saprophyte in the soil it is difficult to see how this can be of any use.

7. Spraying the surface of the soil with Bordeaux Mixture will sometimes prevent the spread of the disease in the seed bed.

III. Mindews. -

(a) True Mildew (Erysiphe Martii). Class: Ascomycetex; Order: Perisporiales.

(b) False Mildew (Peronospora parasitica). Class: Phyconfcetea ; Order: PeronospokALES.

(a) True Mildew. - A species of Erysiphe identical with E. Martii is found on the surface of cruciferous plants-for description see under clover mildew, page 63 .

(b) False Mildew (Peronospora parasitica). Various cruciferous plants are susceptible, but probably swedes suffer most, especially in dry seasons, 
and with early sowing. It often occurs in company with white rust.

Symptoms. - A grey white mould appears on the under side of the leaves; the latter assume at the same time a sickly appearance, shrivel up, and when rain comes, rot with a strong characteristic odour.

Canse.-Peronospora parasitica causes this disease. Its hyphæ grow within the plant (compare

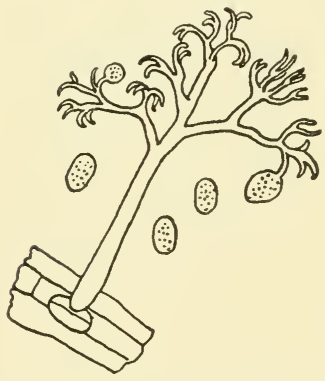

FIG. 29.-Conidiophore of Peronospora parasitica, which causes fa se mildew of swedes, growing through a breathing pore: notice the detached conidia. (Magnified.) (After Frank.) true mildews) and draw nourishment from the cell contents, thereby preventing normal development. Aei ial hyphre are sent out through the stomata, which branch in a tree-like manner, and form, at the tips, colourless conidia (Fig. 29) which fall off easily and are capable of immediate germination. Resting spores (oospores) with a thin yellowish outer wall are formed, on the mycelium within the plant, as a result of sexual union. 'These develop the following spring.

Preventive Measures.-On account of the widespread nature of the fungus, little can be done.

I. Keep down all cruciferous weeds.

2. Sow swedes later in the dry warm districts, 
3. Apply nitrate of soda, as a top-dressing.

4. Frequent horse-hoeing even in the late summer has in many cases been found beneficial.

IV. White Rust (Albugo candida. Kuntz. ; Cy'-

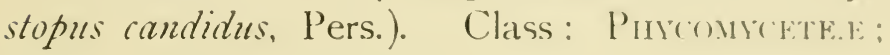
Order: Peronosporales.

This fungus attacks various cruciferous plants, but is especially abundant on shepherd's purse (Capsella bursa pastoris) where it appears as a lime-white covering causing deformity of the stems, leaves, and leaf-stalks.

The mycelium grows within the host; later it bursts through the surface, forming spores (in chains) (Fig. 30) which constitute the white powder. 'These spores are carried by the wind, and in the presence of moisture give rise to zoospores which swim for a time, and on coming to rest, form a germ tube which can enter a cruciferous plant. Resting spores are formed as a re-

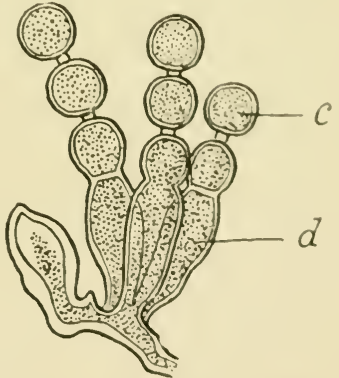

Fig. 30.-White rust (Cy'stopus candidus). P'ortion of the hypha with conidiophores; (d) bearing the conidia (c) in chains. (Magnified.) sult of sexual union, in most plants, but not in shepherd's purse.

V. Buackening of Rape--Rape in particular suffers from the attack of Sporidesmium critiosum, which forms blackish-brown spots, especially on the 
"seed pods," but also on the stem. The pod shrivels and seed formation is prevented.

On account of the wide distribution of the fungus little can be done to prevent it.

VI. Sclerotium Disease (Sclerotimia libertiana; Sclerotinia sclerotionm, Massee). Class: Ascomicetes; Order: Pezizales.

- Rape, swedes, and turnips are attacked in particular. The mycelium is only able to enter the host after being nourished for a time saprophytically. A description of this fungus is given on page 67 , under sclerotium disease of clover.

Since the sclerotia are capable of resting for a long time, and the fungus is able to grow as a saprophyte, little can be done to prevent attack. Liming is to be recommended.

NoTE.-For insect pests of this group see "Farm and Garden Insect Pests," by Somerville. M.M. \& Co. 


\section{CHAPTER VI.}

FUNGOID DISEASES OF MANGELS AND BEET.

I. False Mildew (Peronospora schachtii). Class: Phycomicetea ; Order: Peronosporales. Both mangels and beet are attacked, the latter to a serious extent in France and Germany.

Symptoms. - In May and June the young leaves assume a light green colour, and become crumpled in a blaclder-like form with the outside edges turned under. A grey covering of mycelium is found on the under side. Plants attacked are dwarfed in growth, or may be altogether destroyed. Single plants or patches suffer.

Cause.-The greyish patches on the under side of the leaf consist of conidiophores of the fungus Peronospora schachtii which causes the disease. The conidiophores grow through the stomata and bear at the tips oval-shaped spores that are easily detached and carried by the wind. They germinate readily on a moist surface, and if germination takes place on beet or mangel leaves the germ tube enters and grows within. Resting spores, with thick walls, are formed within the dead leaves, 
and the mycelium remains over the winter in the roots.

\section{Precautions.-}

I. Remove all diseased plants.

2. Grow some other crop for a year or two.

3. Keep down weeds.

II. Leaf Spot (Cercospora beticola). Fungi Imperfecti; Order: Moniliales.

Both mangels and sugar beet are attacked.

Symptoms. - Very small grey round spots, with a dark red circumference, appear on the leaf in summer, consisting of conidiophores bearing long, tail-like, colourless conidia with cross walls. With a few spots only, no serious damage results; if an abundance the plant suffers.

Canse.-The fungus Cercospora beticola causes the disease. The long septate conidia are carried by the wind on to healthy leaves, where they germinate. Growth is limited in area, each spot being the result of a separate infection. Winter spores are not known.

The damage caused is not as a rule serious, and no satisfactory preventive can be given; burn the leaves after harvesting, if the disease is abundant.

III. LeAF BRown (Sporidesmium putrefaciens, Fuckel). Fungi Imperfecti; Order: Monir.ales. Both mangels and sugar beet suffer.

Symptoms.-Appears in late summer and autumn; the oldest leaves are attacked, the 
youngest being free. Differs from leaf spot in that the whole leaf surface turns brown, and thickens.

Cause.-Investigation has shown that on and within the surface of the brown parts the mycelium of S. putrefaciens may be formed. From this mycelium brown hypha arise, bearing at the ends large pear-shaped septate spores, which are very easily detached and carried by the wind. A germ tube grows from each of the chambers.

Preventive Measures. -

1. Remove the leaves of attacked crops.

2. Steep the seed in formaldehyde solution (see p. 32$)$.

IV. Leaf Rust (Uromyces Beta, Tulasne). Class: 'Termospores; Order: Urennares.

This disease is seen on both mangels and sugar beet, especially in those fields where they are grown many years in succession. Damage is not serious.

Symptoms.-Appears on leaves late in the season in the form of small yellowish pustules, the remainder of the leaf remaining a healthy green, unless the spots are exceedingly numerous, in which case it turns a sickly colour. It is chiefly the older leaves that are attacked.

Canse.-The disease is due to Uromyces Betce. The pustules on the leaf consist of uredospores of the fungus; these are blown to healthy plants, there setting up new centres of disease. 
Preventive Measures. -

I. Remove all tops and refuse.

2. Grow mangels on other ground.

3. Spraying with Bordeaux Mixture is recommended, but it is of doubtful value.

V. Beetroot and Mangel Rot (Phoma Bete, Frank). Fungi Imperfecti; Order: SpHaropsiDALES.

Symptoms.-Seen in dry summers during July and August and sometimes later. The young inner leaves become blackened; in bad cases the whole of the leaves suffer, the attack spreading from the inner leaves outward. Later the mangel itself falls a prey to the fungus (this constitutes the dry rot) ; first the epidermis is discoloured, and later the inner tissue becomes brown and dry.

Cause.-The fungus Phoma Bete with its thickish, septate, colourless hyphre is present in the tissues causing disease. Picnidia (small cases containing spores) are seen in the diseased tissue as minute black points. They liberate the spores from a small opening. They may remain in the ground a long time and still be capable of germination when favourable conditions occur.

This fungus is often accompanied by Fusarium beticola, which has crescent shaped spores.

VI. Violet Root Rot (Rhizoctonia violacea). Fungi Imperfecti.

Mangels and beet suffer, though not seriously. 
A purple red covering of mycelium is found on the root, causing rotting. No spores are formed. For description of the fungus, see p. $7 \mathrm{I}$.

Attack is said to be worst on badly drained land.

VII. Beetroot and Mangel Tumour (Oeciomyces leproides, see note on p. I08). Sub-Class: PHycomycetee; Order : Chytriniales.

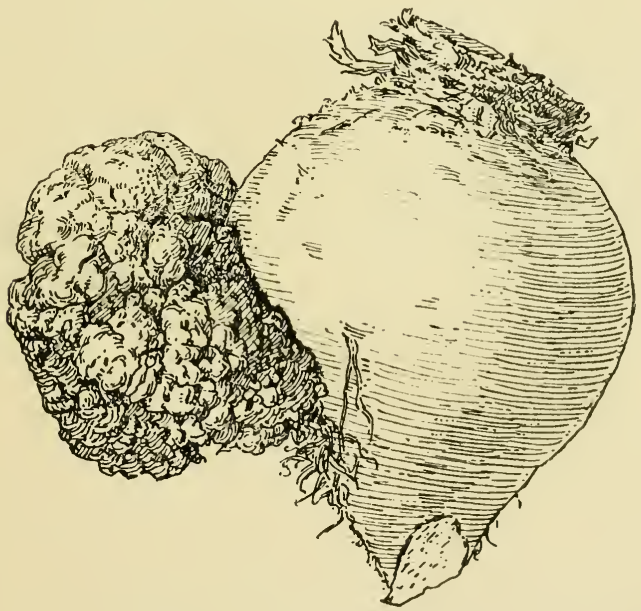

FIG. 3r.-A mangel showing the large tumour on the left side.

(a) Beetroot.-This disease was found near Algiers, and described by Trabut. Large brain-like swellings or fleshy tumours are found above the ground, and are attached to the root by a very narrow neck. Spores are found in small cavities in the tumours.

(b) Mangel. - The author found a similar disease to the above on mangels grown on land heavily 
dressed with gas lime. The swellings were at the soil level, some of them being bigger than the double hand (see Fig. 3I). No fungus mycelium nor spores could be detected within the hypertrophied tissue, but it is conceivable that the fungus found on the beet is also the cause of the mangel tumour. Observation leads him to believe that the parasite enters at the small pits made in the root at the soil level by slug bites, etc. ; there is, however, no direct proof of this.

Note.-Professor Bessey suggests that the tumours may have been caused by the crown-gall bacteria (Pseudomonas tumefacicns) which is known to cause large galls on mangels and other plants. 


\section{APPENDIX.}

\section{FUNGOID DISEASES OF ANINAIS.}

HERE again only those diseases caused by the true fungi will be described; the reader being referred to books on animal pathology for descriptions of the innumerable diseases caused by bacteria.

I. Wooden Tongue (Actinomyces bovis). - Also known as actinomycosis, lumpy jaw, cancer of the tongue, etc. It appears most frequently in the ox, but pigs and human beings are sometimes attacked. In the ox the tongue is the chief seat of disease, but in castrated animals the spermatic cord may become infected; it has also been found in the peritoneum.

Symptoms.-On and within the tongue small flattened, greyish-yellow or reddish nodules or abscesses appear $\frac{1}{5}$ to $\frac{1}{5}$ inch in diameter, microscopic examination revealing the presence of a fungus. These nodules harden and sometimes lime is deposited, giving a granular appearance. The animal. rolls its tongue about, and swallows with difficulty ; saliva drops from the mouth, and the tongue is swollen and hardened. The disease may spread from the tongue to the lower jaw. 
Cause. - The abnormal appearance above noted is caused by the parasitic fungus Actinomyces bovis, which was first discovered by Bollinger about 1877 . Sections through the nodules show that they consist, internally, of loosely arranged knot-like branched hyphæ, which are arranged radially at the periphery of the nodule (hence the term ray fungus), and terminate in a flask-like expansion. Numerous small bodies resembling cocci or bacilli may be found arranged end to end in the swellings, and also liberated and distributed between the hypha; they result from the breaking up of the hyphæ and are called "fragmentation spores".

Most authorities now consider the disease of bacterial origin.

Treatment.-The disease is most difficult to combat. Pricking the tongue with a needle has been recommended, but is of doubtful value. Some: veterinary surgeons advise immediate slaughter; in any case, professional advice should be sought.

Scrape the parts and dress with a solution consisting of equal parts of tincture of iodine and carbolic acid, and give iodide of potash internally (Levie).

II. Ringwory (Oidium tonsurans; Trichophyton tonsurans, Malmsten; Herpes tonsurans). Fungi Imperfecti.

Most frequent on young cattle in poor condition, but also found on horses, goats, and dogs.

Symptoms. - Irregular circular areas appear, 
especially about the face and neck, devoid of hair and varying in size from a fraction of an inch to several inches in diameter. The skin on these bare surfaces is wrinkled, encrusted, and scabbed in appearance. In the earlier stages small bladders are seen from which an evil-smelling substance exudes. These dry up, forming the bark or crust of greyishbrown leathery scales mentioned above.

Cause.-The bladder-like swellings and loss of hair are caused by the parasitic fungus Oidium tonsurans, of which there appear to be several varieties. It grows readily on blood serum, where it forms, on the hypha, chains of roundish oval conidia, which spread the disease. Whether this fungus is identical with the one found on human beings is still an open question.

Remedial Measures.-Clean the parts well by scraping and brushing and afterwards apply one of the following dressings, which must be repeated should occasion require :-

(a) Train oil 5 parts, sulphur I part.

(b) Soft soap 5 parts, sulphur I part.

(c) Olive oil 8 parts, creosotell I part.

Levie recommends the following: wash well'with warm water, washing soda, and soft soap, rub off the crusts with emery paper, and next day when dry paint the parts with the following:-

I oz. Sir Wm. Burnett's disinfecting fluid, 24 oz. water (shake well before using). 
III. Favus in Poultry (Achorion Schonleinii, Remak) (Oidium Schonleinii, Grawitz). Fungi Imperfecti.

Almost all breeds of poultry are attacked, the disease being very contagious, a single case soon contaminating the whole run. 'The discase is also common in children.

Symptoms. - Small, pale, irregular, shield-like pits appear on the comb; and later on the wattles and head. They coalesce, thicken, and becomeyellowishgrey. The feathery parts, especially the breast and neck, may be attacked, the feathers drying up and falling off. The disease is most difficult to combat at this stage, often ending fatally.

Canse.-Oidium Schonleiniz, or a parasitic fungus closely resembling it, causes the above disease, gaining entrance to the comb probably at some abrasion and spreading to the wattles, neck, and breast. Grown on artificial media, the mycelium is greyish white; from it spring soft white fluffy aerial hypha, bearing the conidia in chains. They may be produced in such profusion, both here and on the comb, as to form a dust-like covering over the whole surface. 'The fungus also possesses the following characteristics : is sensitive to acid in the medium, forms a sulphur yellow colouring matter, likes fairly high temperatures, and produces an alkaline by-product .

Remedial Measures.-Always isolate and treat 


\section{FUNGOID DISEASES OF ANIMALS 113}

immediately when seen. Clean the affected parts either by washing well with soft soap and water, or rubbing with emery paper and brushing, and apply any of the following :-

(a) Sulphur ointment.

(b) Paint with iodine solutions.

(c) 5 per cent silver nitrate in lard.

(d) ro per cent solution of carbolic acid.

(e) Mercuric oxide I part, lard $S$ parts.

NoTE.--For insect pests, see "Farm and Garden Insect l'ests," by Somerville. M.M. \& Co. 



\section{INDEX.}

ABNORMaL flowering, 15 .

- fruit, I4.

Achorion Schonlcinii, II2.

Actinomyces bovis, rog.

Actinomycosis, rog.

Adaptability, 22.

Aecidiospores, II, I6, 5I, 55 .

Aerobic, 89.

Albugo candida, гог.

Algæ, 38 .

Alopecurus pratensis, 57.

Anaerobic, 89.

Anbury, 94.

Animals, diseases of, rog-I3.

Anthracnose, 70.

A scochyta pisi, 69 .

Ascomycetea , 35, 36, 38, 55, 58, 63,

67, 99, то2.

Ascospores, 7, 56 .

Ascus, 35, 56.

BACILLUS mesentcroides, 89 .

- phytophthorus, 82 .

- solanisaprus, 82.

Bacteria, I, 89 .

Bad nourishment, 22.

Barley, blackened, 6r.

- covered smut of, 42 .

- deaf ears of, 60.

- leaf brown of, 60.

- naked smut of, 42 .

- rust, 53.

Basidiomycetea, 35,38 .

Beans, diseases of, 63, 74 .

Beetroot, diseases of, 94-102.

Berberis vulgaris, I I, 50, $5 \mathrm{I}$.

Black leg, 82 .

- scab, 85.

Blattrollkrankheit, 83 .

Board of agriculture, 87 .
Bordeaux mixture, 25.

Botrytis cinera, 82 .

Brome smut, 44 .

Bromus mollis, 44 .

Brown rust, 52.

Buckthorn, 54 .

Budding, $9,4 \mathrm{I}$.

Bugloss, 53.

Bủnt, 9, 29, 33, 45 .

Campion, I5.

Cancer of the tongue, rog.

Capsella bursa pastoris, I5, ror.

Carpomycetea, 34.

Cercospora beticola, I04.

Cereals, diseases of, 39,62 .

Centorhyncus sulcicollis, 94.

Chlamydospores, 7,40 .

Chlorophycea, 35 .

Chlorophyll, 2.

Chry'sophlyctis endobiotica, $8_{5}$.

Chytridiales, 85, ro7.

Cilia, 77, 96, 98 .

Cladochytridiacer, 72.

Cladosporium herbarum, 6r.

Claviceps purpurea, 7,55 .

Clostridium butyricum, 89 .

Clovers, diseases of, 63,74 .

Club root, 94 .

Cocksfoot, 54, 57 .

Colletotrichum lindemuthianum, 70 .

Conidia, 7, 4r, 65, 76, Iог

Conidiophore, 4,76 .

Continued cropping, 22.

Contortions, 15.

Copper sulphate solution, 2 S.

Corky scab, 87 .

Corrosive sublimate solution, $3 \mathrm{I}$.

Crowded cropping, 2I.

Crown gall of clover, 72 . 
Crown rust, 53.

Cruciferous plants, diseases of, 94 . 102.

Curly dwarf, $80, s_{\uparrow}$.

- leaf, $8 \mathrm{o}, 8_{4}$.

Cuscuta Trifolii, 74 .

DACTYLIS glomerata, 54,57 .

Damage done by fungi, 23 .

Damping off, 97 .

Discoloration, $15,17,59$.

Disease, conditions favourable, 20.

- - unfavourable, 23.

- diagnosis of, 17.

- signs of, 16 .

- spread of, 18.

Dodder, 74.

Drop cultures, 8.

Dry rot, ro6.

- - of potatoes, 88 .

EFFECT of parasite, 13.

Endophytic, I3.

Endospores, 7.

Entomophthorales, 35 .

Epichloe typhina, 57.

Epidermis, 20.

Epiphytic, 13.

Ergot, 55.

Erysiphe, 5, 12, 13, 65, 66.

- graminis, 58, 64 .

- Martii, 63, 99.

Euphorbia, 67.

Evergood, 90, 92.

Exoascus pruni, I4.

Favus in poultry, II 2.

Ferrocyanide test, 27.

Festuca silvatica, 54 .

Finger-and-toe, 19, 21, 94.

Flourball, 92.

Formaldehyde solutions, 32 .

Fungi, 1 .

- classification of, 34 .

- damage done by, 23.

- how plant is entered by, 19.

Fungi imperfecti, 36, 38, 61, 62, $69-72,80,84,88,90$, 104, 106, I IO- 12.

Fungicides, 24.

Fusarium solani, 7, 88 .

- species, 15, 82, 88 .
Germ tube, 19.

Germination of spores, 7 -10, 47,77 .

Golden rust, 52.

Grass, black spots on, 62 .

- diseases of, 39.

HaUstoria, 5.

Helminthosporium gramine $u m, 60$.

- teres, 62.

Higher lungi, 34 .

Host, diversity in, 22.

- influence of, 15 .

Hot water treatment, 29.

Hyphæ, 2, 3 .

INFECTED tubers, $7 \delta$.

KRÄUSELKRANKHEIT, $\varepsilon_{0}, 83$.

LANGWORTHY, 87 .

Lathyrus, 63,67 .

Leaf, brown, I04.

- curl, 80.

- roll, 83 .

- rust, 105.

- spots, 62, 73, 104.

Leguminous plants, diseases of, 63 , 74.

Lenticels, 92.

Leptospharia Tritici, 6o.

Lime sulphur, 33.

Litmus paper, 27.

Liver of sulphur, 3 r.

Loose smut of barley, 42.

- - of wheat, 43.

Lower fungi, 35 .

Lucerne, diseases of, 67, 71, 72 .

Lumpy jaw, rog.

Lychnis dioica, 15 .

MACROSPORIUM sarcinaforme, 72 .

- solani, 8 o.

Maize, smut of, 44.

Mangels, diseases of, 103-8.

Meadow foxtail, 57 .

Nildew, 3, r2, 13, 49, 63-66, 99, ro3.

- downy, 66.

- false, $64,99$.

Moniliales, 6I, 72, 88, 90, тон.

Mucor mucedo, 4, 7, 13, 82 .

Mucorales, 35. 
Mycelium, 2, 3 .

Myxomycetes, 94.

Nourishment, influence of, 22.

OATs, leaf brown of, 62 .

- smut of, 39.

Oidium lactis, 7.

- schonleinii, Ir2.

- tonsurans, rro.

Oogonia, 79 .

Oospora scabics, 84 .

Oospores, 7,78 .

Parasites, $2, x_{2}, 64$.

Peas, diseases of, $63-74$.

Penicillium glaucum, 7,13 .

Perisporiales, 58, 64, 99, I01, 103.

Perithecia, 56.

Peronospora parasitica, 99.

- schachtii, 103.

- Trifoliorum, 64 .

- vicia, 64.

Peronosporales, 35, 63, 66, 75, 99ror, ro3.

Pezizales, 67, 68, 102.

Phellomyces scicrotiophorus, 88 .

Phoma beta, гоб.

Phycomycetea, $34,35,38,64,66$, $72,75,85,97$, I03, I07.

Phyla, 34 .

Phyllachora graminis, 62.

- Trifolii, 73.

Physiological derangement, 80,83 .

Phytophthora erythroseptica, 79, 90.

- infestans, I2, I3, I6, I8-21, 66, $75-80$

- Phaseoli, 66.

Picnospores, Ir.

Pisum , 63, 67.

Plasmodiophora brassica, 20, 22, 94.

Plasmodiưm, 95.

Pocket plums, I 4 .

Polyporis, I3, 20.

Potato, diseases of, 75.93.

Powdery scab, 87 .

Premature buds, 15 .

Preparation of tungicides, 26.

Promycelium, 4r, 47 .

Protococcoidea, 35 .

Protoplasm, 2, 95.
Pseudomonas tumefaciens, 108.

Pseudopeziza medicaginis, 73.

- Trifolii, 73.

Puccinia coronata, 53 .

- coronifera, 54 .

- dispersa, 52.

- glumarum, 52, 53 .

- graminis, 5, 10, I4, I6, 49, 67.

- rubigo vera, 52 .

- simplex, 53.

- straminis, 52.

Pustule, 50, 52.

Pyrenomycetales, 55, 57.

Pythium de Baryanum, 97.

Ray fungus, IIo.

Reproduction, ro.

Rhizoctonia violacea, I5, 71, 106.

Rhodophycea, 35 .

Ringworm, IIO.

Root hairs, I4, 20, 96.

Rust, I0, I2, I4, 48, 66.

Rust-free wheat, 48 .

Rye, ergot of, 55 .

- smut of, 43 .

SAPROLEGNIALES, 35, 97.

Saprophytes, 2, 6, I 2.

Scab of potatoes, 84,85 .

Sclerotia, 4, 57, 67, 68 .

Sclerotinia libertiana, I02.

- sclerotiorum, 19, I02.

- Trifoliorum, 67.

Sclerotium disease of clover, 67.

Septoria avena, 6 o.

- briosiana, 60.

- glumarum, 6 o.

- gramineum, 6 o.

Sheep's fescue, $5+$.

Shepherd's purse, 15.

Siphonophycea, 34 .

Slime fungi, 95 .

Smother fungus, 57.

Smut, 9, 12, 15, 29, 32, 39- +s.

Soda Bordeaux, 28.

Soft brome, 45 .

Spharella exilialis, 60.

Spharopsidale's, 69, ro6.

Spicaria nivea, 9J.

Sporangiophore, 4 .

Spores, $4,7,47$.

- distribution of, $7,18,23$. 
Spores, germination of, 7 .

Sporidesminm exitiosum, ror.

- putrefaciens, I04.

Spot disease of peas, 69 .

- - of potatoes, 90.

Sprain, 93.

Spring rust, 52.

Spurge, 67.

Stem rot of potatoes, 82 .

Stinking smut, $43,45$.

Straw, blackening of, $6 r$.

Streak, 93.

Stroma, 56 .

Sulphur, 34 .

Synchytriacee, 35 .

Synchytrium endobioticum, 85 .

TALL oat grass, smut of, 45 .

Teleutospores, II, I6, 50 .

Teliosporea, $34,36,38,39,45,48$, 66, 105.

Teliospores, 40, 50 .

Tests for Bordeaux mixture, 27.

Tilletia, 9, 4I, 45 .

Tilletiacea, 36,45 .

Trichophyton tonsurans, тाо.

Trimethylamine, 46 .

UREDinales, I2, 36, 48, 66, I05.

Uredospores, II, I6, 50, 54 .

Urocystis Agropyri, 44 .

- occulta, 43 .

Uromyces apiculatus, 67 .

- Beta, I05.

- phaseolorum, 67.
Uromyces pisi, 67 .

- striatus, 67.

- Trifolii, 67.

Urophlyctrs alfalfa, 72 .

Ustilago, 9, I5, 39.

- avena, 39.

- bromivora, 44.

- hordei, 42.

- Fensenii, 42 .

- lavis, 39.

- Maydis, 44 .

- mida, 42.

- perennans, 45.

- Secalis, 44 .

- Tritici, 43 .

Ustilaginales, 36, 39-45.

Vegetable kingdom, 37 .

Vicia, 63-66.

Violet root rot, 7I, Io6.

WART disease, 85 .

Weather, influence of, 20.

Wet rot, 89 .

Wheat, browning of, 59 .

- bunt, 45 .

- mildew of, 58 .

- rust of, 49.

- smut of, 4I, 43.

White rust, I5, I6, Ior.

Witches' broom, I5.

Wooden tongue, rog.

Zoospores, 20, 77, 98. Zygospores, 7 . 


\section{BOOKS ON AGRICULTURE, PLANT LIFE, ETC.}

RESEARCHES ON FUNGI : an Account of the Production, I iberation and Dispersion of the Spores of Hymenomycetes treated Botanically and Physically. Also some Observations upon the Discharge and Dispersion of the Spores of Ascomycetes and of Pilobolus. By A. H. RegiNal, BLI.t.k, B.Sc. (Lond.), D.Sc. (Birm.), Ph.D. (Leip.). With 5 Plates and 83 Figures in the Text. Royal 8vo, 12s. 6d. net.

A POPULAR TREATISE ON THE IPHYSIOLOGY OI: PLANTS. By Dr. PAUt, Sorauler. Translated by F. E. WeIss, B.Sc., F.L.S. With 33 Illustrations. 8vo, 9s, net.

DISEASES OF PLANTS INDUCED BY CRYPTOGA.UIC PARASITES. Introduction to the Study of Pathogenic Fungi, Slime Fungi, Bacteria and Algx. By Dr. Karl. Freiherr von Tubeuf, Privatdocent in the University of Munich. English Edition by WilLias G. S.sith, B.Sc., Ph.D., Lecturer on Plant Physiology, University of Edinburgh. With 330 Illustrations. Royal 8 vo, 18 s. net.

AGRICULTURAL ANALYSIS. A Manual of Quantitative Analysis for Students of Agriculture. By Fraxk T. Addvana, B.Sc. (Lond.), F.1.C. With 49 Illustrations. Crown $8 v o, 5 s$, net.

MAIZE, ITS HISTORY, CULTIVATION, HANDLING AND USES, with Special Reference to South Africa. A Text book for Farmers, Students of Agriculture, and Teacher's of Nature Study. 13y-JOSEPH BURTT-1)AIY, F.L.S., F.R.G.S., Government Agrostologist and Botanist, Departinent of Agri eulture, Union of South Africa. WVith Frontispiece and 245 Illustrations. Iledium $8 v 0,25$ s. net.

PRACTICAL AGRICULTURAL, CHEMISTRI. BY J. BERNARI Colemas, A.R.C.S.C., F.I.C., and Frank T. Adviman, B.Sc. (Lond.), F.I.C. With 24 Illustrations. Crown 8 vo, $2 \mathrm{~s}$, net.

A FOUNDATION COURSE IN CHEMISTRY FOR STUDENTS OF AGRICULTURE AND TECHNOLOGY. By J. W. Dongsos. 13.Sc. (Lond.), Lecturer in Chemistry at University College, Reading, and J. AlAs Mlurray, B.Sc. (Edin.), Lecturer in Agricultural Chemistry at University College, Reading. With Diagrams. Crown $8 v 0,3 \mathrm{~s}, 6 \mathrm{~d}$. net.

\section{Worlis BY C. F. CROSS AND E. J. BEVAN.}

CEILULOSE: an Outline of the Chemistry of the Structural Elements of Plants. With Reference to their Natural History and Industrial Uses. (C. F. Cross, E. J. Bevas, and C. BEadle.) With 14 Plates. Crown 8 vo, 12s. net.

RESEARCHES ON CELLULOSE, I., 1895-1900. Crown 8vo, fis. net. RESEARCHES ON CELLULOSE, II., 1900-1905. Crown sio, 7s. 6d. net.

RESEARCHES ON CELLUI,OSE, III., 1905-1910. With specimens of "Cellophane" film (Viscose process) manufactured by the Soc. Anonyme, Blanchisserie et Teinturerie de Thaon (les Vosges). Crown 8vo, 7s, 6d, net.

\section{WORKS BY SIR RIDER HAGGARI).}

A FARMER'S YEAR: being his Commonplace Book for 1sis. With 2 Maps and 36 Illustrations by G. LEos LITTLE. Crown 8vo, 3s. 6d. net.

RURAL ENGLAND : being an Account of Agricultural and Social Researches. With 75 Illustrations from Photographs, 2 vols. 8vo, 12s.

RURAL DENMARK AND ITS LESSONS. With Frontispicec. Crown 8 vo, 3s. $6 \mathrm{~d}$.

\section{LONGMANS, GREEN AND CO.,}

LONDON, NEWV YORK, BOMBAY, CALCUTTA, AND MADRAS. 


\section{BOOKS ON AGRICULTURE, PLANT LIFE, ETC. \\ (Continued).}

THE CHEMISTRY OF CATTLE FEEDING AND DAIRYING. By J. Alan Murray, B.Sc., Lecturer in Agricultural Chemistry at University College, Reading. With Illustrations and Folding Chart. Crown $8 \mathrm{vo}, 6 \mathrm{~s}$. net.

ENGLISH FARMING, PAST AND PRESENT. By Rowland E. Prothero, late Fellow of All Souls College, Oxford; Agent in Chief to the Duke of Bedford. 8vo, 12s. 6 d. net.

SOIL CONDITIONS AND PLANT GROWTH. By EDWARD J. Russell, D.Sc. (Lond.). Goldsmiths' Company's Soil Chemist, Rothamsted Experimental Station, Harpenden. With Diagrams. 8vo, 5s, net. (.11onographs on Biochemistry.)

ARTIFICIAL MANURES : THEIR CHEMICAL SELECTION AND SCIENTIFIC APPLICATION TO AGRICULTURE. By II. GeOrges VIlle, F.R.S. Revised by Sir WIlliam Crookes, D.Sc., F.R.S., and JohN Percival, Mi.A., Director of the Department of Agriculture, University College, Reading. With 6 Plates. 8vo, 10s, 6d, net.

AN INTRODUCTION TO THE CHEMISTRY OF PLANT PRO. DUCTS. By PAUL HAAS, D.Sc., Ph.D., Demonstrator in Organic and Applied Chemistry and in Chemical Physiology at the University College, London; and T. G. HILL, A.R.C.S., F.L.S., Reader in Vegetable Physiology in the University of London, University College. With Diagrams. 8vo, 7s. 6d. net.

THE PROFITABLE CULTURE OF VEGETABLES FOR MARKET GARDENERS, SMALL HOLDERS, AND OTHERS. BY THOMAS Sмith, F.R.H.S., Manager of the Fels Fruit Farm and Mayland French Garden. With numerous lilustrations. 8vo, 5s. net.

\section{WORKS BY JOHN WEATHERS, F.R.H.S.}

A PRACTICAL GUIDE TO GARDEN PLANTS. With 163 Diagrams. $8 \%$, 21 s. net.

A PRACTICAL GUIDE TO SCHOOL, COTTAGE AND ALLOT. MENT GARDENING. With 66 Illustrations and Examination Questions on Cottage Gardening. Crown 8vo, 2s. 6d. net.

THE PRACTICAL SCHOOL GARDEN NOTE AND RECORD BOOK. Adapted for use in School Gardens, Horticultural and Agricultural Colleges, Private Gardens, etc. Fcap. 4to, 6d.

Works by HENRY J. WEBB, Ph.D., B.Sc. (LoNd.).

ELEMENTARY AGRICULTURE. A Textbook specially adapted to the requirements of the Board of Education, the Junior Examination of the Royal Agric iltural Society, and other Examinations. With 34 lllustrations. Crown 8 ro, 2s. $6 \mathrm{~d}$.

AGRICULTURE. A Manual for Advanced Science Students. With 100 Illustrations. Crown 8vo, 7s, 6d, net.

\section{LONGMANS, GREEN AND CO.,}

LONDON, NEWY YORK, BOMBAY, CALCUTTA, AND MADRAS, 




\section{SB733 Mew York Botanical Garden Lbrary}

SB733.M48
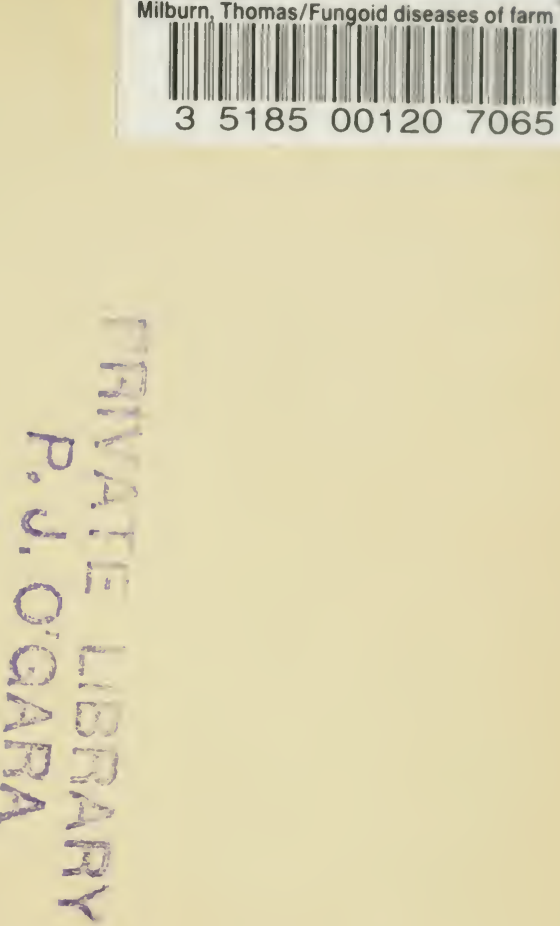
2.

H.

\subsection{4}

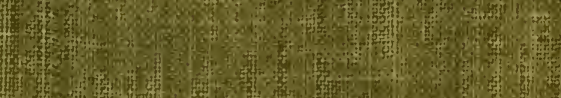

(2)

(1)
H.

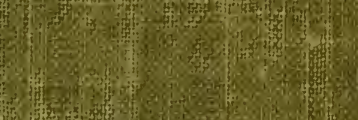

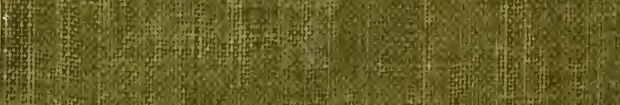

(3)

5.

W.

(5)

$7 r^{2}+2$

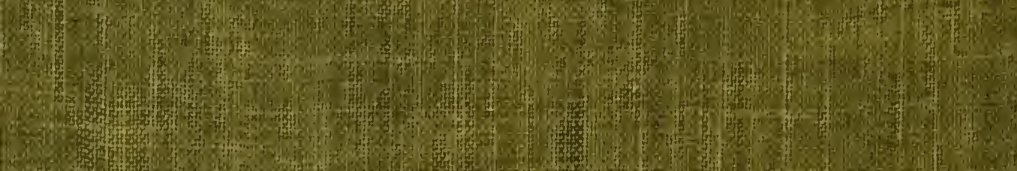

